Winter 2012

\title{
Human Rights and the Elusive Universal Subject: Immigration Detention Under International Human Rights and EU Law
}

\author{
Cathryn Costello \\ Worcester College, Oxford, cathryn.costello@worc.ox.ac.uk
}

Follow this and additional works at: https://www.repository.law.indiana.edu/ijgls

Part of the European Law Commons, Human Rights Law Commons, Immigration Law Commons, and the International Law Commons

\section{Recommended Citation}

Costello, Cathryn (2012) "Human Rights and the Elusive Universal Subject: Immigration Detention Under International Human Rights and EU Law," Indiana Journal of Global Legal Studies: Vol. 19 : Iss. 1 , Article 10.

Available at: https://www.repository.law.indiana.edu/ijgls/vol19/iss1/10

This Symposium is brought to you for free and open access by the Law School Journals at Digital Repository @ Maurer Law. It has been accepted for inclusion in Indiana Journal of Global Legal Studies by an authorized editor of Digital Repository @ Maurer Law. For more information, please contact rvaughan@indiana.edu.

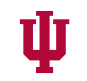

JEROME HALL LAW LIBRARY

INDIANA UNIVERSITY

Maurer School of Law
Blooming ton 


\title{
Human Rights and the Elusive Universal Subject: Immigration Detention Under International Human Rights and EU Law
}

\author{
CATHRyn Costello*
}

\begin{abstract}
The right to liberty is ubiquitous in human rights instruments, in essence protecting all individuals from arbitrary arrest and detention. Yet, in practice, immigration detention is increasingly routine, even automatic, across Europe. Asylum seekers in particular have been targeted for detention. While international human rights law limits detention, its protections against immigration detention are weaker than in other contexts, as the state's immigration control prerogatives are given sway. In spite of the overlapping authority of international and regional human rights bodies, the caselaw in this field is diverse. Focusing on the U.N. Human Rights Committee, the European Court of Human Rights, and the Court of Justice of the European Union, this Article explores how greater interaction between these bodies could produce more rights-protective standards.
\end{abstract}

\section{INTRODUCTION}

The right to liberty is ubiquitous in human rights instruments, in essence protecting all individuals from arbitrary arrest and detention. It should go without saying that deprivations of liberty

* Fellow and Tutor in EU and Public Law at Worcester College, Oxford. I thank participants at the 2011 Nordic Asylum Law Seminar on The State of International Refugee Law; the Indiana Journal of Global Legal Studies Spring Symposium on Globalization and Migration; the VU University Amsterdam Seminar on Migration Law and European Integration, Bergen aan Zee; and the Workshop on the Meaning and Practice of Immigration Detention, St. Antony's College, Oxford for helpful comments on earlier drafts, in particular Galina Cornelisse, Catherine Dauvergne, Jeff King, Gregor Noll, and Thomas Spijkerboer. I am particularly indebted to Aaron Rathmell for research assistance and to the Journal's reviewers and editorial staff for their helpful suggestions. Unless otherwise noted, all translations are my own. The usual disclaimer applies.

Indiana Journal of Global Legal Studies Vol. 19 \#1 (Winter 2012)

(C) Indiana University Maurer School of Law 
require the strongest possible justification. Yet, in practice, immigration detention ${ }^{1}$ is increasingly routine, even automatic, across Europe. ${ }^{2}$ Often detention is justified on the basis that categories of immigrants are "illegal," either in entering a state's territory without authorization or in staying after they have been told to leave. Asylum seekers in particular have been targeted for detention. ${ }^{3}$ While international human rights law (IHRL) ${ }^{4}$ limits detention, we see that the protections afforded to migrants are often weaker than in other contexts. 5 The state's migration control powers seem to be given greater sway than others, reflecting an uneasy

1. "Immigration detention" is understood as referring to the detention of migrants (in the broadest sense, to include all individuals entering the territory of a state other than their own, be it as refugees, asylum-seekers, stateless persons, irregular migrants, or regular migrants) either upon seeking entry to a territory or pending deportation, removal, or return from a territory.

2. See generally CoUNCIL OF EUR., PARL. Ass., Report of the Comm. on Migration, Refugees and Population on the Detention of Asylum Seekers and Irregular Migrants in Europe, Doc. No. 12105 (2010); ANA CATARINA MENDONÇA, Explanatory Memorandum to The Detention of Asylum SeEkers and IrRegular Migrants IN Europe (2010); Michael Flynn \& Cecilia Cannon, Global Detention Project, Detention at the BORDERS OF EUROPE: REPORT ON THE JOINT GLOBAL DETENTION PROJECTINTERNATIONAL DETENTTON COALITION WORKSHOP IN GENEVA, SWITZERLAND, 2-3 OCTOBER 2010 (2010).

3. See generally Michael Welsh \& Liza Schuster, Detention of Asylum Seekers in the US, UK, France, Germany and Italy: A Critical View of the Globalizing Culture of Control, 5 CRIMINOlogy \& CRIM. JuST. 331 (2005).

4. "International human rights law" is used here to connote the broad body of international law that is rooted in the Universal Declaration of Human Rights (UDHR) and the two key covenants: the International Covenant on Civil and Political Rights (ICCPR) and the International Covenant on Economic Social and Cultural Rights (ICESCR). It also includes the regional human rights instruments, in the European context being those of the Council of Europe, principally the European Convention on Human Rights (ECHR) and the European Social Charters (ESC). For present purposes, I focus on the ICCPR and ECHR. Also pertinent is the Refugee Convention (RC) (Geneva Convention of 28 July 1951 and the Protocol of 31 January 1967 relating to the status of refugees). The RC may not, on one view, be part of IHRL, because its main function is palliative, in that it only applies when flight to another country triggers its legal protections. However, I include it within the notion of IHRL here as the key instrument that sets out the rights and obligations of states towards a vulnerable category of foreigners, namely asylum seekers and refugees. Space precludes considering detention of children, so for that reason alone the Convention on the Rights of the Child (CRC) is not examined.

5. See generally ALICE .EDWARDS, BACK TO BASICS: THE RIGHT TO LIBERTY AND SECURITY OF PERSON AND 'ALTERNATIVES TO DETENTION' OF REFUGEES, ASYLUM-SEEKERS, Stateless Persons and Other Migrants (2011); INT'l Detention Coal., Legal Framework aND STANDARDS RELATING TO THE DETENTION OF REFUgEes, AsYlum SEEKERS AND MigRANTS: A GUIDE (2011); INT'L COMM'N OF JURISTS, MigRATION AND INTERNATIONAL Human RIGHTS LAW: PRACTITIONERS GuIDE No. 6, at 147-90 (2011). 
tension between the universal right to liberty and the state's border control prerogatives. My starting point is the acknowledgment of this tension. I set out to examine how it is resolved over time when migrants challenge their detention before human rights courts and bodies. ${ }^{6}$

Accordingly, this Article focuses in particular on the roles of the U.N. Human Rights Committee (HRC), the European Court of Human Rights (ECtHR or Strasbourg), and the Court of Justice of the European Union (CJEU or Luxembourg) in this context. The HRC is the monitoring body for the International Covenant for Civil and Political Rights (ICCPR), while the ECtHR is the court that enforces the European Convention on Human Rights (ECHR). The CJEU is the main court of EU law. Since 1997, the EU Member States have conferred competence on the European Union (EU) to adopt binding laws relating to immigration, asylum, and "combating illegal immigration" from outside the EU. ${ }^{7}$ Now, there is a significant body of EU law governing immigration detention, in particular, the detention of asylum seekers under the Procedures Directive (PD) ${ }^{8}$ and Reception Conditions Directive (RCD) ${ }^{9}$ and of those facing deportation under the Returns Directive (RD). ${ }^{10}$ Thus, as of late, the CJEU has become part

6. The principal focus is on the permissibility of detention per se, rather than procedural protections and detention conditions, although the latter also raise serious human rights concerns, usually scrutinized under guarantees against inhuman and degrading detention conditions. See, e.g., European Convention on Human Rights art. 3, opened for signature Nov. 4, 1950, C.E.T.S. no. 194. Particular concerns are also raised in relation to the detention of children. See, e.g., Mayeka \& Mitunga v. Belgium, App. No. 13178/03 Eur. Ct. H.R. (2006) http://www.echr.coe.int/echr/en/hudoc (follow "HUDOC database" hyperlink; search "Application Number 13178/03"). As will be seen though, the two issues are intertwined, as detention conditions do bear on the permissibility of detention, in particular under the case law of the European Court of Human Rights, discussed below at infra Part II.C.

7. Consolidated Version of the Treaty on the Functioning of the European Union art. 79(1), May 9, 2008, 2008 O.J. (C 83) 47, 77 [hereinafter TFEU] (stating aims for the development of an EU common immigration policy).

8. See Council Directive 2005/85/EC, On Minimum Standards on Procedures in Member States for Granting and Withdrawing Refugee Status, 2005 O.J. (L326) 13 [hereinafter PD] (this directive is currently being revised, and the outcome of the reform process is not yet clear). See also Amended Proposal for a Directive of the European Parliament and of the Council on Common Procedures for Granting and Withdrawing International Protection Status, COM (2011) 319 final (June 1, 2011).

9. Council Directive 2003/9, Laying Down Minimum Standards for the Reception of Asylum Seekers, 2003 O.J. (L31) 18 [hereinafter RCD] (this directive is being revised at present). See Amended Proposal for a Directive of the European Parliament and of the Council Laying Down Standards for the Reception of Asylum Seekers, COM (2011) 320 final, (June 1, 2011).

10. See Directive 2008/18, of the European Parliament and of the Council of 18 December 2008 on Common Standards and Procedures in Member States for 
of the apparatus of supranational human rights adjudication over the bulk of immigration detention by EU Member States. ${ }^{11}$

The main aim of this article is to analyze the jurisprudence of all three bodies on immigration detention. In comparing and contrasting their different jurisprudence, I illustrate how different human rights bodies speak with different voices on detention, a phenomenon that is at least in part explained by their different institutional contexts and decisional autonomy. ${ }^{12}$ Given that the resultant human rights standards overlap significantly, I urge greater mutual engagement between regimes, so that a "constructive human rights pluralism" might emerge, drawing on a thesis developed at length elsewhere. ${ }^{13}$ Constructive human rights pluralism describes the desirable mode of interaction between human rights regimes, whereby each cultivates a degree of openness to the others, while maintaining its own integrity. ${ }^{14}$

Returning Illegally Staying Third-Country Nationals, 2008 O.J. (L 348) 98 [hereinafter RD].

11. This article focuses on the easy case where Member States implement these directives in detaining third-country nationals (TCNs) and are therefore subject to EU norms. It is also arguable that in other situations Member State detention practices may fall within the scope of EU law, in particular if the detention practices derogate from other EU norms.

12. Of course, the degree of decisional autonomy or "zone of discretion" (to use Sweet's term) will only be a crude indicator. As he puts it,

Mapping a zone of discretion cannot tell us what constitutional courts [a term he applies to the ECtHR, CJEU and WTO Appellate Body] will actually do with their powers. The best we can do is to predict that, given a steady case load, constitutional judges operating in a relatively larger zone will come to exercise more influence over the evolution of the polity than those operating in relatively smaller zones.

Alec Stone Sweet, Constitutionalism, Legal Pluralism, and International Regimes 16 IND. J. OF GLOBAL LEGAL STUD. 621, 640-41 (2009).

13. Cathryn Costello, Destination Europe: Human Rights \& Admissions to the EU's Area of Freedom, Security and Justice (Jan. 14, 2010) (unpublished doctoral thesis in law, University of Oxford) (on file with author). See Miguel Poiares Maduro, Interpreting European Law: Judicial Adjudication in a Context of Constitutional Pluralism, 1 EUR. J. Legal STUD. 1 (2007). See also Miguel Poiares Maduro, Courts and Pluralism: Essay on a Theory of Judicial Adjudication in the Context of Legal and Constitutional Pluralism, in RULING THE WORLD? CONSTITUTIONALISM, INTERNATIONAL LAW, AND GLOBAL GOVERNANCE 356 (Jeffrey Dunoff \& Joel Trachtman eds., 2009).

14. This piece focuses on the interactions across key international and regional regimes, rather than between the international and domestic. On the latter, see generally Gerald L. Neuman, Human Rights and Constitutional Rights: Harmony and Dissonance, 55 STAN. L. REv. 1863 (2003); Gráinne de Búrca \& Oliver Gerstenberg, The Denationalization of Constitutional Law, 47 HARV. INT'L L. J. 243 (2006); Anne-Marie Slaughter \& William Burke-White, The Future of International Law is Domestic (or, The European Way of Law), 47 HARV. INT'L L. J. 327 (2006). 


\section{TOWARDS Constructive HuMAN Rights PluRALISM}

\section{A. Human Rights Between Universalism and Statism}

Human rights tend to be conceived of as universal, in that they are rights all people have simply in virtue of being human. That premise sits uneasily with statist border control, which presupposes rights enjoyed within bounded states that have a sovereign right to control admissions. A distinctive conception of sovereignty dominates immigration discourse and law, tending to equate sovereignty and unfettered state discretion. ${ }^{15}$ I refer throughout to the "statist entry control assumption" or, simply, the "statist assumption" to connote this notion that states have a sovereign right to exclude aliens without justification. Undoubtedly, this notion warrants challenge on ethical grounds ${ }^{16}$ and cries out for historical corrective. ${ }^{17}$ The statist assumption seems out of place in an age of human rights and increasing transnational economic and social interpenetration. Yet, in the migration context, it remains stubbornly ingrained. ${ }^{18}$

This statist assumption is reflected in the Universal Declaration of Human Rights (UDHR) and percolates through other instruments. The UDHR speaks of "the right to a nationality" but not in the country of one's residence or choosing. It affirms the right "to freedom of movement and residence," but only "within the borders of each State,"19 and the "right to leave any country, including his own, and to return to his country,"20 but not to enter another. Article 14(1) of the UDHR enshrines the right to seek, but not to be granted, asylum, stating "everyone has the right to seek and to enjoy . . . asylum from persecution." The formulation was controversial, reflecting states' unease at inclusion of a right to be granted

15. See generally GaLINA CoRnelisse, IMMigration DETENTION AND HUMAN Rights: RETHINKING TERRITORIAL SOVEREIGNTY (2010) (arguing that it is a distinctively territorial account that distorts human rights in the immigration field).

16. See generally Veit Bader, The Ethics of Immigration, 12 Constellations 331 (2005).

17. For critiques of the presentation of the statist assumption in light of the historical development of public international law, see James A. R. Nafziger, The General Admission of Aliens Under International Law, 77 AM. J. INT'L L. 804 (1983); Satvinder S. Juss, Free Movement and the World Order, 16 INT'L J. REFUGEE L. 289 (2004).

18. See, e.g., Catherine Dauvergne, Making People Illegal: What globalization MEANS FOR MIGRATION AND LAW (2008); Catherine Dauvergne, Sovereignty, Migration and the Rule of Law in Global Times, 67 MOD. L. REV. 588 (2004).

19. Universal Declaration of Human Rights art. 13(1), G.A. Res. 217(III) A, U.N. Doc. A/RES/217(III) (Dec. 10, 1948) [hereinafter UDHR].

20. Id. art. 13(2). 
asylum, lest it create a subjective right to enter their territory. ${ }^{21}$ Broadly speaking, both the ICCPR ${ }^{22}$ and the ECHR ${ }^{23}$ follow this pattern. Even the Refugee Convention (RC) does not create a right of admission to the territory per se. ${ }^{24}$ As Seyla Benhabib puts it, "a series of internal contradictions between universal human rights and territorial sovereignty are built into the logic of the most comprehensive international law documents in our world."25

Scholars examining the tensions between human rights and border control tend to fall within three broad categories. Yasemin Soysal exemplifies the universal. She argues that the development of IHRL marked a transition from nationality to humanity as the primary reference for the enjoyment of rights, diminishing the distinction between citizens and aliens. ${ }^{26}$ On the other extreme, we find scholars who emphasize the persistent significance of migration control and alienage within IHRL. ${ }^{27}$ Rather than open up space to resolve tensions between universal human rights and migration control, IHRL tends to reify this conflict, supporting the statist assumption. In this vein, it has been suggested that the international legal character of IHRL instruments tie

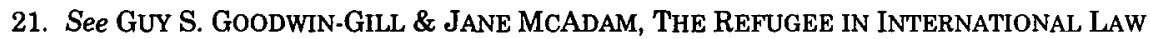
358-61 (3d ed. 2007).

22. International Covenant on Civil and Political Rights, G.A. Res. 2200A (XXI), 21 U.N. Doc. A/6316 (Dec. 16, 1966), 999 U.N.T.S. 171, entered into force Mar. 23, 1976 [hereinafter ICCPR].

23. Protocol No. 4 to the Convention for the Protection of Human Rights and Fundamental Freedoms, Securing Certain Rights and Freedoms Other than Those Already Included in the Convention and in the First Protocol Thereto, art. 2, 3, Sept. 16, 1963, E.T.S. No. 46.

24. As Goodwin-Gill and McAdam put it, "[s]tates were not prepared to include in the [RC] any article on admission of refugees; non-refoulement in the sense of even a limited obligation to allow entry may well have been seen as coming too close to the unwished-for duty to grant asylum." GooDWIN-GILL \& MCADAM, supra note 21, at 206-07. See Charter of Fundamental Rights of the European Union art. 18, Dec. 7, 2000, 2000 O.J. (C 364) 1, 12 (stating that, "The right to asylum shall be guaranteed with due respect for the rules of the [RC] and in accordance with the Treaty establishing the European Community") [hereinafter EUCFR]. But see Maria-Teresa Gil-Bazo, The Charter of Fundamental Rights of the European Union and the Right to be Granted Asylum in the Union's Law, 27 REFUGEE SURVEY Q. 33, 34 (2008) (arguing that EUCFR art. 18 indicates that, "the right to be granted asylum has become a subjective right of individuals under the Union's legal order").

25. Seyla Benhabib, The Rights of Others: Aliens, Residents, and Citizens 11 (2004).

26. See generally YASEMIN SOYSAL, LIMITS OF CITIZENSHIP MIGRANTS AND POSTNATIONAL MEMBERSHIP IN EUROPE (1994).

27. See, e.g., Linda Bosniak, Universal Citizenship and the Problem of Alienage, 94 Nw. U. L. REV. 963 (2000). 
them to the state system. ${ }^{28}$ Accordingly, norms that manifest state sovereignty "alter and shape human rights provisions." 29 This Article locates itself on the more ambivalent middle terrain, inspired by the work of Benhabib. She identifies the apparently "irresolvable contradiction" between universal human rights and democratic self-determination..$^{30}$ Yet, while she accepts that this apparent contradiction cannot be overcome, she argues that it can be mediated and mitigated through "democratic iterations" including "jurisgenerative politics." 31 These are the deliberative processes in which universalist rights claims are contested and contextualized. ${ }^{32}$ Courts are exemplars of "strong public bodies" 33 engaged in these processes, as are other human rights adjudicatory bodies like the HRC. The ECtHR has unsettled statist border control assumptions, albeit in tentative fashion. Relocating matters of asylum and immigration into the EU realm is replete with further transformative potential.

\section{B. A Plurality of Overlapping Instruments and Institutions}

Overlapping, even competing, human rights jurisdiction is the institutional reality. ${ }^{34}$ The authority of the HRC and the ECtHR overlap, as all Council of Europe members are also parties to the ICCPR. ${ }^{35}$ Although the HRC may decline to hear complaints if the

28. See generally SALADIN MECKLED-GARCIA \& BASAK ÇALI, Lost in Translation: The Human Rights Ideal and International Human Rights Law, in THE LEGALIZATION OF Human Rights: Multidisciplinary Perspectives on Human Rights and Human RIGHTS LAW 11 (2006).

29. Id. at 16.

30. Id. at 19 .

31. Id. at 176-81. See generally Robert M. Cover, Foreword: Nomos and Narrative, 97 HARV. L. REv. 4 (1983); Frank Michelman, Law's Republic, 97 YALE L.J. 1493 (1988).

32. See MECKLED-GARCfA \& ÇALI, supra note 28, at 179. See also Seyla Benhabib, Claiming Rights Across Borders: International Human Rights and Democratic Sovereignty, 103 AM. POL. SCI. REV. 691 (2009).

33. MECKLED-GARCLA \& ÇALI, supra note 28, at 179 (distinguishing between "strong" public bodies like the legislature, judiciary, and executive, and "weak" publics of civil society associations and the media). My account differs in that it focuses not so much on domestic public bodies so much as international and supranational ones.

34. See generally Liora Lazarus, Cathryn Costello, Nazila Ghanea, and Katja Zeigler, Study for Parliament on the Evolution of Fundamental Rights Charters and Case Law: A Comparison of the United Nations, Council of Europe and European Union Systems of Human Rights Protection, Directorate-General for Internal Policies (Feb. 2011), available at http://www.europarl.europa.eu/activities/committees/studies/download.do?language=en\&file $=34751$.

35. For a list of parties to the ICCPR, see Databases, UNITED NaTions TREATY COLLECTION, http://treaties.un.org/Pages/ViewDetails.aspx?src=TREATY\&mtdsg_no=IV. 4\&chapter=4\&lang=en (last visited Mar. 2, 2012). 
matter is already before the ECtHR, ${ }^{36}$ it inevitably pronounces on issues (if not individual complaints) that are also raised before the ECtHR given that both instruments deal with similar civil and political rights. All EU Member States are parties to the ECHR, and the EU itself is about to accede. ${ }^{37}$ Pending accession, the EU institutions have internalized ECHR standards, and the CJEU uses them to scrutinize both the validity of EU acts ${ }^{38}$ and of pertinent national ones. ${ }^{39}$ The ECtHR, for its part, has deferred to the autonomy of the EU system, satisfied that the EU generally provides "equivalent protection" of human rights. ${ }^{40}$ In order to rebut this presumption, applicants must demonstrate "manifestly deficient" protection within the EU system. ${ }^{41}$ Most EU law is implemented by the EU Member States, and provided they exercise some discretion in so doing, they remain answerable before the ECtHR for their actions. ${ }^{42}$ When EU Member States detain third-country national (TCN) migrants, they are increasingly within the scope of EU law, giving the CJEU jurisdiction as well.

Four vivid illustrations of the overlapping Luxembourg/Strasbourg jurisdictions are pertinent and current. First, the individual at the center of the CJEU's first ruling on predeportation detention $(K a d z o e v)^{43}$ still has a case pending before the ECtHR concerning the

36. Catherine Phuong, The Relationship Between the European Court of Human Rights and the Human Rights Committee: Has the 'Same Matter' Already Been 'Examined?, 7(2) HUM. RTS. L. REV. 385, 394 (2007).

37. See Consolidated Version of the Treaty on European Union art. 6(2), Dec. 13, 2007, 2008 O.J. (C 115) 13, 19 (stating that, "The Union shall accede to the [ECHR]. Such accession shall not affect the Union's competences as defined in the Treaties") [hereinafter TEU]. See also Council of Europe Informal Group on Accession of the European Union to the Convention, Final Version of the Draft Legal Instruments on the Accession of the European Union to the European Convention on Human Rights (July 19, 2011), available

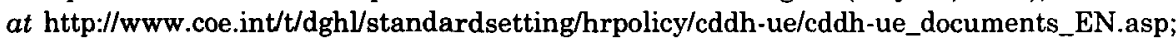
Tobias Lock, EU Accession to the ECHR: Implications for Judicial Review in Strasbourg 35 EUR. L. REV. 777 (2010).

38. E.g., Case C-540/03, Parliament v. Council, 2006 E.C.R. I-5769.

39. E.g., Case C-60/00, Carpenter v. Sec'y of State for the Home Dep't, 2002 E.C.R. I-6279.

40. Bosphorus Hava Yollari Turizm Ve Ticaret Anonim Sirketi v. Ireland, 42 Eur. Ct. H.R. 1, 46 (2005). See generally Cathryn Costello, The Bosphorus Ruling of the European Court of Human Rights: Fundamental Rights and Blurred Boundaries in Europe, 6 HUM. RTS. L. REV. 87 (2006); Tobias Lock, Beyond Bosphorus: the European Court of Human Rights' Case Law on the Responsibility of Member States of International Organizations Under the European Convention on Human Rights, 10 HUM. RTS. L. REv. 529 (2010) (providing an account of the jurisprudential developments since the Bosphorus decision).

41. See Bosphorus, 42 Eur. Ct. H.R. at 46.

42. See M.S.S. v. Belgium \& Greece, App. No. 30696/09 Eur. Ct. H.R. (2011), http://www.echr.coe.int/echr/en/hudoc (follow "HUDOC database" hyperlink; search "Application Number 30696/09").

43. Case C-357/09 PPU, Kadzoev, 2009 E.C.R. I-11189. 
lawfulness of his detention under the ECHR. ${ }^{44}$ Second, the CJEU's other ruling on predeportation detention (El-Dridi) ${ }^{45}$ raises some similar issues on the detention-deportation nexus, as were considered by the ECtHR only weeks before in Mikolenko v. Estonia. ${ }^{46}$ Third, Strasbourg recently ruled on the duties of EU Member States when transferring asylum seekers under the EU's Dublin Regulation ${ }^{47}$ in M.S.S. v. Belgium \& Greece. ${ }^{48} \mathrm{~A}$ case on similar issues has been argued before the CJEU. ${ }^{49}$ Fourth, the most recent ECtHR case on detention of asylum seekers, Lokpo \& Touré v. Hungary,50 concerned detention under domestic legislation adopted to give effect to the EU PD.51 The applicants in any of these cases could invoke the ICCPR, if not domestically, then by complaining to the HRC about their treatment.

IHRL has a common metaframework in the UDHR. ${ }^{2}$ On this basis, some cross-fertilization, perhaps even leading to an international jus commune on human rights across various human rights instruments, may be envisaged. Certainly, convergence across different human rights instruments and bodies would seem to be desirable with a view to ensuring coherence and equality. ${ }^{53}$ Such convergence raises fewer difficult institutional questions than the integration of human rights

44. Kadzoev v. Bulgaria, App. No. 56437/07 Eur. Ct. H.R. (introduced Dec. 20, 2007 and communicated Feb. 2, 2009).

45. See Case C-61/11 PPU, Hassen El-Dridi alias Karim Soufi, 2011 ECJ EUR-Lex CELEX LEXIS 1027 (Apr. 28, 2011).

46. Mikolenko v. Estonia, App. No. 10664/05, Eur. Ct. H.R. (2009), http://www.echr.coe.int/echr/en/hudoc (follow "HUDOC database" hyperlink; search "Application Number 10664/05").

47. See Council Regulation 343/2003, Establishing the Criteria and Mechanisms for Determining the Member State Responsible for Examining an Asylum Application Lodged in One of the Member States by a Third-Country National, 2003 O.J. (L 50) 1 (EC).

48. See M.S.S. v. Belgium \& Greece, App. No. 30696/09 Eur. Ct. H.R. (2011), http://www.echr.coe.int/echr/en/hudoc (follow "HUDOC database" hyperlink; search "Application Number 30696/09").

49. Press Release, Opinions of the Advocate General in Joined Cases C-411/10 N.S. v. Secretary of State for the Home Dep't and C-493/10 M.E. and Others v. Refugee Applications Commissioner and Minister for Justice, Equality and Law Reform (Sept. 22, 2011) [hereinafter Opinions of AG Trstenjak in $N S / M E]$.

50. Lokpo \& Touré v. Hungary, App. No. 10816/10 Eur. Ct. H. R. 7, para. 16 (2011), http://www.echr.coe.int/echr/en/hudoc (follow "HUDOC database" hyperlink; search "Application Number 10816/10").

51. Id. para. 15.

52. See, OLIVIER DE SchuTTER, INTERNATIONAL HUMAN RIGHTS LAW 31-32 (2010) (Whether they are adopted at the universal or the regional levels, all human rights treaties are derived from the UDHR, from which they borrow, sometimes quite literally, much of their language. It is therefore quite natural for international courts or quasijudicial bodies ... to cite one another.").

53. This is not to suggest that convergence is in all cases desirable. Convergence at the lowest common denominator is clearly undesirable. 
standards into other regimes, such as those dealing with international trade or investment, where that integration may be seen to expand the functional regime's scope. ${ }^{54}$ Indeed, the sort of mutual engagement between overlapping human rights systems advocated here is much less contentious than the citation of foreign law sources across constitutional jurisdictions. ${ }^{55}$ While all three of the bodies under discussion here, the HRC, the ECtHR, and the CJEU, are charged with enforcing a particular instrument or body of law, they also have the means, and indeed, the obligation, to take into account other instruments and jurisprudence. For instance, the ECHR contains a provision referring to obligations under other human rights instruments. ${ }^{56}$ Similarly, the EU Charter of Fundamental Rights (EUCFR), a binding part of EU law since 2009, and the general principles of EU law, which contain binding fundamental rights norms predating the Charter, are both synthetic in character, drawing on outside human rights standards. ${ }^{57}$

For instruments with broader scope to influence the narrower regional ones seems entirely fitting. In particular, it is legally and institutionally problematic for the ECHR standards to fall below the

54. See Anne Van Aaken, Defragmentation of Public International Law Through Interpretation: A Methodological Proposal, 16 IND. J. GLOBAL LEGAL STUD. 483, 483 (2009).

55. See, e.g., Christopher McCrudden, Judicial Comparativism and Human Rights, in Comparative Law: A HandbooK 371 (Esin Örücü \& David Nelken eds., 2007). As Waters notes, much of the U.S. debate conflates the citation of "foreign" domestic sources and international law. Melissa Waters, Creeping Monism: The Judicial Trend Toward Interpretative Incorporation of Human Rights Treaties, 107 COLUM. L. REV. 628 (2007).

56. The ECHR provides in Article 53 (ex Article 60), entitled "Safeguard for Existing Human Rights," that "nothing in this Convention shall be construed as limiting or derogating from any of the human rights and fundamental freedoms which may be ensured under the laws of any High Contracting Party or under any other agreement to which it is a Party." European Convention on Human Rights, supra note 6, art. 53.

57. Charter of Fundamental Rights of the European Union, art. 6(1), 2007 O.J. (C 303) 1. The TEU now provides that, "The Union recognizes the rights, freedoms and principles set out in the Charter of Fundamental Rights of the European Union of 7 December 2000, as adapted at Strasbourg, on 12 December 2007, which shall have the same legal value as the Treaties. . . " The Charter contains Article 53, entitled "Level of Protection," which provides:

Nothing in this Charter shall be interpreted as restricting or adversely affecting human rights and fundamental freedoms as recognized, in their respective fields of application, by Union law and international law and by international agreements to which the Union or all the Member States are party, including the European Convention for the Protection of Human Rights and Fundamental Freedoms, and by the Member States' constitutions.

Id. Furthermore, Article 52(3) provides the EUCFR rights which "correspond" to ECHR rights and shall have the same meaning and scope, although EU law may provide higher protection. On this provision, see Opinions of AG Trstenjak in NS/ME, supra note 49, ๆๆ $142-48$. 
ICCPR. The ICCPR embodies a global minimum; it is undesirable, not only legally, but also institutionally, for a regional system to fall below that standard. Individuals from regions with developed human rights systems should not have to look to protection at the U.N. level. When they do, it signals a double failure, at both the domestic and the regional level. In contrast, for the narrower regional system to prompt progressive developments in the broader one may raise objections from the states that are not party to the narrower regional system. Nonetheless, under certain conditions it may be appropriate. For instance, EU standards may provide evidence for an evolving consensus that the ECtHR should regard according to its own established interpretative methodology. ${ }^{58}$ Also, there are means whereby the wider system may reinforce the narrower one. For instance, the Strasbourg Court sometimes takes into account Member States' obligations under EU law in assessing states' limitation of certain rights, ${ }^{59}$ or even in determining whether states meet their positive duties under absolute guarantees such as Article 3 of the ECHR. 60

This Article is also concerned with the particular legal position of asylum seekers and refugees, so the RC is pertinent. This instrument lacks a dedicated court or monitoring body. ${ }^{61}$ Given that absence, asylum seekers and refugees in Europe often have recourse to the ECtHR, as the Strasbourg system offers comparative enforcement advantages over the RC. ${ }^{62}$ Over the years, Strasbourg has developed an extensive jurisprudence on asylum seekers and refugees, taking into account, but not enforcing, the RC. ${ }^{63}$ For instance, the ECtHR in Amuur

58. See, Camille Dautricourt, A Strasbourg Perspective on the Autonomous Development of Fundamental Rights in EU Law: Trends and Implications (Jean Monnet Working Paper No. 10/10, 2010), available at http://centers.law.nyu.edu/jeanmonnet/papers/10/101001.html, 30-35.

59. Mendizabal v. France, App. No. 51431/99 Eur. Ct. H. R. (2006), http://www.echr.coe.int/ echr/en/hudoc (follow "HUDOC database" hyperlink; search "Application Number 51431/99"). See also the varying examples in Dautricourt, supra note 58, at 36-39.

60. Thus, controversially, in M.S.S v. Belgium \& Greece the ECtHR had regard to Greece's obligations under the EU RCD to assess whether its treatment of asylum seekers was "inhumane and degrading" contrary to Article 3 ECHR. See, M.S.S. v. Belgium \& Greece, App. No. 30696/09 Eur. Ct. H.R. (2011), http://www.echr.coe.int/echr/en/hudoc (follow "HUDOC database" hyperlink; search "Application Number 30696/09").

61. Convention Relating to the Status of Refugees, July 28, 1951, 189 U.N.T.S. 137 [hereinafter RC]. The RC states parties may, under Article 38, accord the ICJ jurisdiction over the instrument. However, this jurisdiction has never been invoked, leading to what is known as the "Article 38 deficit."

62. Hélène Lambert, Protection Against Refoulement from Europe: Human Rights Law Comes to the Rescue, 48 INT'L \& COMP. L. Q. 543 (1999).

63. See generally NuALa Mole \& CATHERINe MEREDith, ASYlum AND THE EuRopean CONVENTION ON HUMAN RIGHTS (2010). 
v. France noted, but did not explore, the import of the $\mathrm{RC}$ on detention. ${ }^{64}$ Similarly, the ECtHR protects many asylum seekers and refugees from removal, bolstering and extending the RC's non-refoulement guarantee. ${ }^{65}$ The EU, for its part, legislates on asylum and refugee matters. In so doing, it is required to adopt measures which are "in accordance with the $[\mathrm{RC}]$ and other relevant treaties." 66 In legislating on the scope of refugee protection in Europe, the EU codified not only the RC concept of persecution "within the meaning of article $1 \mathrm{~A}$ of the $[\mathrm{RC}]$," 67 but also a broader notion of serious harm encompassing some of the ECHR non-refoulement protection and some protection for those fleeing indiscriminate violence. 68

Notwithstanding IHRL's common basis in a set of metaprinciples, and the appropriateness of cross-referencing between different systems, the specter of a fragmentation of IHRL looms. While the ECtHR has integrated various other human rights standards, it has done so in a somewhat piecemeal and inconsistent way. ${ }^{69}$ The CJEU's use of sources other than the ECHR has been "parsimonious."70 In particular, the CJEU has been strikingly dismissive of the jurisprudence of quasijudicial bodies, including the HRC. It noted that the HRC is "not a

64. Amuur v. France, App. No. 19776/92 Eur. H.R. Rep. para 43 (1996).

Such confinement, accompanied by suitable safeguards for the persons concerned, is acceptable only in order to enable States to prevent unlawful immigration while complying with their international obligations, particularly under the 1951 Geneva Convention Relating to the Status of Refugees and the European Convention on Human Rights. States' legitimate concern to foil the increasingly frequent attempts to circumvent immigration restrictions must not deprive asylum-seekers of the protection afforded by these conventions.

65. However, it has also been suggested that in demanding a high degree of individuation of risk in order to trigger protection from removal, "the coexistence of the two systems [RC and ECHR] appears to have aggravated the restrictive tendencies of both-in other words, competition between the two systems has resulted in constraining the protection opportunities of asylum seekers, instead of amplifying them, as it should." Jean François Durieux Salah Sheekh is a Refugee: New Insights into Primary and Subsidiary Forms of Protection (Refugee Studies Centre Working, Paper No. 49, 2008).

66. See TFEU, supra note 7-the pertinent provision is now Article 78 (1).

67. Council Directive 2004/83, art. 9(1), On Minimum Standards for the Qualification and Status of Third Country Nationals or Stateless Persons as Refugees or as Persons Who Otherwise Need International Protection and the Content of the Protection Granted, 2004 O.J. (L 304) 12 (QD).

68. See id., art. 15. See also Elgafaji v. Staatssecreteris van Justitie, App. No. 465/07 Eur. Ct. H.R. (2009), http://www.echr.coe.int/echr/en/hudoc (follow "HUDOC database" hyperlink; search "Application Number 465/07").

69. See generally MAgDalena Forowicz, THE RECEPTION OF INTERNATIONAL LAW IN THE EUROPEAN COURT OF HUMAN RIGHTS (2010).

70. Israel Jesús Butler \& Olivier de Schutter, Binding the EU to International Human Rights Law, 27 Y.B. OF EUR. L. 277, 282 (2008). 
judicial institution" and that its "findings [had] no binding force in law."71 While it is appropriate for one body to take into account the others' institutional context when reading its output, the CJEU position is too dismissive. Its characterization of the HRC is certainly at odds with the HRC's self-perception. ${ }^{72}$ As will be seen, immigration detention also is a domain where the appropriate constructive engagement is lacking.

\section{Contrasting Institutional Contexts}

Although both the ECtHR and CJEU are evidently courts, their institutional setup differs significantly. The ECtHR is accessible only once domestic remedies have been exhausted. Nonetheless, it disposes of a massive, growing caseload, acting as a supranational court for human rights across the forty-seven countries of the Council of Europe. The ECtHR is now inundated with cases, and reforms have been undertaken to allow it to deem more cases inadmissible and dispose of cases more efficiently. ${ }^{73}$ Although the ECHR is under some accounts characterized as a constitutional instrument, ${ }^{74}$ its domestic effect varies across contracting states. ${ }^{75}$

The CJEU, in contrast, has jurisdiction over a range of different actions against the EU institutions and the Member States, to ensure compliance with the vast body of EU law, including treaties, legislation, and general principles. Most of the CJEU's caseload comprises references from national judges, often concerned (albeit indirectly) with the compatibility of domestic laws and practices with EU norms. Unlike the HRC and the ECtHR, the CJEU is not exclusively or even predominantly a human rights court. Its human rights jurisdiction arises where there are some pre-existing questions of EU law. EU human rights norms then bind the EU institutions and the Member States when they act within the scope of EU law. ${ }^{76}$

71. Case C-249/96, Grant v. South-West Trains Ltd., 1998 E.C.R. I-621, para. 46.

72. See generally infra notes 87.89 .

73. Council of Eur., Protocol 14 The Reform of the European Court of Human RIGHTS FACT SHEET, available at www.echr.coe.int/NR/rdonlyres/57211BCC-C88A-43C6B540-AF0642E81D2C/0/CPProtocole14EN.pdf.

74. See, e.g., Alec Stone Sweet, Sur la constitutionalisation de la Convention européenne des droits de l'homme conçue comme une Cour constitutionnelle, 80 REVUE TRIMESTRIELLE DES DROITS DE L'HOMME 923 (2009).

75. For an overview, see generally, A EUROPE OF RIGHTS: THE IMPACT OF THE ECHR ON NATIONAL LEGaL SYSTEMS (Helen Keller \& Alec Stone Sweet eds., 2008).

76. The phrase "within the scope of EU law" is contentious. The binding EU Charter of Fundamental Rights purports to bind the EU Member States only when they are "implementing" EU law (Article 51(1) EUCFR); although it may be interpreted to 
In exercising their judicial review tasks, both courts must be mindful of securing compliance with their rulings. In this endeavor, Strasbourg is in a weaker position than Luxembourg, in that it lacks the direct line of communication with national judges inherent in the preliminary reference procedure, and it has a wider and more diverse pool of states to keep in check. For Karen Alter, "[the CJEU] is about the most powerful and influential international court that is realistically possible." 77 These institutional positions have led to different approaches to the domestic status of EU and ECHR law. The ECHR requires domestic incorporation, ${ }^{78}$ while the CJEU obliges national judges to give EU law full effect, interpreting domestic law to comply with EU law, 79 and, if necessary, to set aside conflicting domestic norms. ${ }^{80}$ Should the national court have any doubts as to the meaning or effect of any particular EU provision, it may refer questions to the CJEU. 81

Contrasting domestic statuses both reflect and temper the courts' respective jurisprudence on national remedies. The ECtHR's starting point is that it is a subsidiary organ, and the primary guarantors of ECHR rights are the Member States. In contrast, the CJEU stipulates

encompass the same scenarios as the broader phrase "within the scope of EU law." See generally Dautricourt, supra note 58, at 49-51; Opinions of AG Trstenjak in $N S / M E$, supra note 49.

77. Karen Alter, The European Court of Justice's Political Power Across Space and Time 3 (Nw. Univ. Sch. of Law and Econ., Working Paper No. 09-03, 2009).

78. See generally, Rick Lawson, The Monitoring of Fundamental Rights in the Union as a Contribution to the European Legal Space (III): The Role of the European Court of Human Rights (Reflexive Governance in the Pub. Interest, Working Paper No. REFGOV. FR-7, 2006).

79. This doctrine of "indirect effect" has its origins in Case C-106/89, Marleasing SA v. La Comercial Internacional de Alimentacion SA, 1990 E.C.R. I-4135. For an application in the EU refugee law context, see C-465/07, Elgafaji v. Staatssecreteris van Justitie, 2009 E.C.R. I-921.

80. See Case 106/77, Amministrazione delle Finanze dello Stato v. Simmenthal S.p.A., 1978 E.C.R. 629. For an application in the context of immigration detention, see Case C-61/11 PPU, Hassen El-Dridi alias Karim Soufi, 2011 ECJ EUR-Lex CELEX LEXIS 1027 (Apr. 28, 2011).

81. Before the entry into force of the Treaty of Lisbon, under Article 68 EC only national courts and tribunals "against whose decisions there is no judicial remedy under national law" were empowered to refer questions concerning EU asylum and immigration law. See generally Steve Peers, EC Immigration Law and EC Association Agreements: Fragmentation or Integration? 34 EUR. L. REV. 628 (2009). However, the Treaty of Lisbon has removed this anomalous restriction so that all national courts and tribunals may make such references. For the most part, whether to refer is in the discretion of the national judge, although judges of final instance are obliged to refer questions of EU law, which are necessary to resolve the case before them, unless the matter is already settled and clear. Article 267 TFEU. Case 283/81, Srl CILFIT \& Lanificio di Gavardo SpA v. Ministry of Health, 1982 E.C.R. 3415. 
duties for national judges directly, reflecting their shared role as EU law judges. As a result, the ECtHR case law on remedies is more tentative than that of the CJEU. In particular, concerning migration status, the ECtHR tends to leave states control over formal migration status, even when it deems individuals to be nonremovable for human rights reasons. ${ }^{82}$ However, the CJEU does not hesitate in deeming that EU law creates stable residence rights in other EU Member countries for those who come within its scope. ${ }^{83}$ The overall result is captured in Virginie Guiraudon's stylized contrast between the CJEU and the ECtHR. She posits a "bold [CJEU] and a tamer [ECtHR]" and predicts "that the [CJEU] will have less fear of increasing its competence and [issuing] controversial rulings, while the [ECtHR] will adopt a selflimiting approach to slowly gain legitimacy and avoid provoking nationstates." 84 We can see some hints of that prediction coming to pass in the immigration detention case law.

The ICCPR's monitoring body, the HRC, has been empowered to examine individual complaints since 1985.85 While its scrutiny of states' regular reports forms the bulk of its work, it is becoming increasingly court-like in its adjudication of individual grievances. ${ }^{86}$ While initially it was assumed that its decisions (known as views) in response to these individual complaints were not legally binding as such, over time the HRC has asserted that states do have an obligation to allow both views and interim measures ${ }^{87}$ to take legal effect within their national legal

82. See, e.g., Bonger v. Netherlands, App. No. 10154/04, Eur. Ct. H.R. (2005), http:/www.echr.coe.int/echr/en/hudoc (follow "HUDOC database" hyperlink; search "Application Number 10154/04").

83. See, e.g., Case 48/75, Joel Noel Royer, 1976 E.C.R. 497; Case C-60/00, Carpenter v. Sec'y of State for the Home Dep't, 2002 E.C.R. I-6279; Case C-127/08, Metock v. Minister for Justice, Equal. \& Law Reform 2008 E.C.R. I-6241. Admittedly, these cases concern EU Citizens and their TNC family members. However, where TCNs derive rights of residence from other EU measures, we see similar approaches emerging. E.g., Case C-578/08, Chakroun v. Minister van Buitenlandse Zaken, 2010 E.C.R. I-1839.

84. Virginie Guiraudon, European Courts and Foreigners' Rights: A Comparative Study of Norm Diffusion, 34 INT'L MIGRATION REV. 1088, 1094 (2000).

85. See Liz Heffernan, A Comparative View of the Individual Petition Procedures under the European Convention on Human Rights and the International Covenant on Civil and Political Rights, 19 HuM. RTS. Q. 78 (1997); see generally Dominic McGoldrick, The Human Rights Committee: Its Role in the Development of the International Covenant on Civil and Political Rights (1991).

86. ForowICZ, supra note 69 , at $152-53$.

87. See Weiss v. Austria, U.N. Human Rights Comm., 77th Sess., Comm. No. 1086/2002 at 11.1, U.N. Doc. CCPR/C/77/D/1086/2002 (May 24, 2002). The HRC decision was cited by the ECtHR when it established an analogous principle in Mamatkulov v. Turkey, App. Nos. 46827/99 \& 46951/99 Eur. Ct. H.R. Feb. 4, 2005, http://www.echr.coe.int/echr/en/hudoc (follow "HUDOC database" hyperlink; search "Application Number 46827/99"). For 
order. ${ }^{88}$ The domestic effects of the ICCPR vary greatly in practice though. ${ }^{89}$ The HRC may find violations and specify a particular remedy. Compliance is then monitored through a process of periodic review. ${ }^{90}$ The institutional differences sketched in this part will illuminate the substantive discussion in the next part.

\section{IMMIGRATION DETENTION \& HUMAN RIGHTS}

Immigration detention is garnering increasing attention in international human rights fora. Within the U.N. system, the Working Group on Arbitrary Detention (WGAD) has considered immigration detention since 1997.91 The U.N. Special Rapporteur on the Human Rights of Migrants ${ }^{92}$ and the U.N. High Commissioner for Human Rights have also engaged with this issue. ${ }^{93}$ Within the Council of Europe, the Committee of Ministers adopted the Twenty Guidelines on Forced Return in 2005,94 while its Parliamentary Assembly adopted an

discussion of this development as a manifestation of the emerging jus commune of human rights, see Butler \& de Schutter, supra note 70, at 37-39.

88. André Nollkaemper \& Rosanne Van Alebeek, The Legal Status of Decisions by Human Rights Treaty Bodies in National Law 2 (Amsterdam Center for International Law, Research Paper No. 2011-02, Apr. 11, 2011); Scott Davidson, Intention and Effect: The Legal Status of the Final Views of the Human Rights Committee, 2001 N.Z. L. REV. $125,131-32$ (2001).

89. See Christopher Harland, The Status of the International Covenant on Civil and Political Rights (ICCPR) in the Domestic Law of State Parties: An Initial Global Survey Through UN Human Rights Committee Documents, 22 HUM. RTs. Q. 187, 189 (2000).

90. For a defense of this dialogic process, see Michael O'Flaherty, The Concluding Observations of United Nations Human Rights Treaty Bodies, 6 HuM. RTS. L. REV. 27 (2006).

91. Human Rights Commission Res.1997/5 (15 Apr. 1997); UN Docs. E/CN.4/1999/63 (1998), E/CN.4/2004/3 (2003), E/CN.4/2006/7 (2005), A/HRC/10/21 (2008), and A/HRC/13/30 (2010). A specific recent report on Italy deals extensively with immigration detention. See Report of the WGAD on its Mission to Italy, UN Docs A/HRC/10/21/Add.5 (2009) [hereinafter Report of the WGAD].

92. Special Rapporteur on Migrant Workers, Report of the Special Rapporteur, Ms. Gabriela Rodriguez Pizarro, U.N. Comm'n on Human Rights, UN Doc. E/CN.4/2003/85 (Dec. 30, 2002) (by Gabriela Rodriguez Pizarro); Special Rapporteur on the Human Rights of Migrants, Promotion and Protection of All Human Rights, Civil, Political, Economic, Social and Cultural Rights, Including the Right to Development, Human Rights Council, UN Doc. A/HRC/11/7 (May 14, 2009) (by Jorge Bustamante).

93. See Immigration Control Must Not Compromise Human Rights, OFFICE of THE UNITED NATIONS HIGH COMM'R (Sept. 22, 2009), http:/www.ohchr.org/EN/NEWSEVENTS/ Pages/MigrationPanel.aspx.

94. CoUnCIL OF EUR., CoMm. OF Ministers, Twenty Guidelines on Forced Return, 925th Meeting of the Ministers' Deputies (May 4, 2005) [hereinafter Twenty Guidelines on Forced Return]. The Parliamentary Assembly prompted the compilation of these 
important resolution and recommendation in early 2010 specifically on immigration detention..$^{95}$ Significantly, an UNHCR-OHCHR Global Roundtable on Alternatives to Immigration Detention was held in May 2011 in Geneva. ${ }^{96}$ Additionally, the EU's Fundamental Rights Agency (FRA) recently reported on preremoval detention. ${ }^{97}$ These political initiatives, and the soft law principles espoused therein, form an important backdrop to this article.

\section{A. International Covenant on Civil and Political Rights (ICCPR)}

As discussed below, while one might expect the weak institutional framework of the ICCPR to produce tentative rulings on immigration detention, the HRC has developed a relatively robust line of jurisprudence. ${ }^{98}$ Detention must be lawful and nonarbitrary in order to meet the Article 9 standards. ${ }^{99}$ While the notion of lawfulness is similar to that employed by the ECtHR, as will be seen, the HRC notion of arbitrariness is thicker, connoting "elements of inappropriateness, injustice and lack of predictability" as well as reasonableness and necessity "in all the circumstances for a specific purpose." 100 In this context, the HRC also applies the principle of proportionality. ${ }^{101}$

Article 9 does not expressly limit the legitimate purposes of detention, unlike Article 5 of the ECHR. However, the HRC has clarified that detention must pursue a specific purpose. Crucially, for immigration detention purposes, illegal entry alone does not justify

guidelines. EUR. PARL. ASS., Expulsion Procedures in Conformity with Human Rights and Enforced with Respect for Safety and Dignity, 3d Sitting, Doc. No. 9196, (2002).

95. See EuR. PARL. AsS., The Detention of Asylum Seekers and Irregular Migrants in Europe, Doc. No. 12105 (Jan. 11, 2010).

96. See U.N. High Comm'r for Refugees \& U.N. High Comm'r for Human Rights, Concept Note on the Global Roundtable on Alternatives to Detention of Asylum-Seekers, Refugees, Migrants and Stateless Persons (May 11-12, 2011), http://www.unhcr.org/ 4dde23ab9.pdf.

97. See Fundamental Rights Agency, Detention of Third-Country Nationals in Return Procedures, at $80-81$ (2010), available at http://fra.europa.eu/fraWebsite/research/ publications/publications_per_year/pub_detention_en.htm\#.

98. For an extensive analysis, see generally CORNELISSE, supra note 15.

99. "Everyone has the right to liberty and security of person. No one shall be subjected to arbitrary arrest or detention. No one shall be deprived of his liberty except on such grounds and in accordance with such procedures as are established by law." ICCPR, supra note 22 , at art. 9.1 .

100. Human Rights Comm., van Alphen v. Netherlands, Commc'n No. 305/1988, I 5.8, U.N. Doc. CCPR/C/39/D/305/1988 (1990).

101. Human Rights Comm., A. v. Australia, Commc'n. No. 560/1993, ๆ 9.2, U.N. Doc. CCPR/C/59/D/560/1993 (1997). 
detention. ${ }^{102}$ In this respect, the $\mathrm{HRC}$ has set a more demanding standard than the ECtHR in its case law on "detention to prevent unauthorised entry."103 The HRC demands that there are other additional factors particular to the individual, "such as the likelihood of absconding and lack of cooperation, which may justify detention for a period."104

Not only must detention pursue a narrow specific aim, it must be necessary and proportionate in the individual circumstances. ${ }^{105}$ The HRC repeatedly condemned Australia's detention practices for failure to provide individual justifications. ${ }^{106}$ Detention may not be justified on the basis of the country's "general experience that asylum seekers abscond if not retained in custody," 107 an assumption that does not appear grounded in empirical reality in any event. ${ }^{108}$ In $C$. $v$. Australia, ${ }^{109}$ the HRC condemned a detention where the state had failed to assess whether other means (such as the imposition of reporting obligations, sureties, or other conditions) would have met the aim of ensuring compliance with immigration law. ${ }^{110}$ In contrast, in Jalloh $v$. Netherlands, the detention in question was found justified as the applicant had previously fled an open facility. ${ }^{111}$

102. Id. para. 9.4 .

103. See infra Part II.C.3.

104. Human Rights Comm., A. v. Australia, Commc'n. No. 560/1993, ๆ 9.4, U.N. Doc. CCPR/C/59/D/560/1993 (1997).

105. Id. para. 9.2 .

106. See generally id.; Human Rights Comm., Saed Shams v. Australia, Comm. No. 1225/2004, CCPR/C/90/D/1255 (2007); Human Rights Comm., D and E and Their Two Children v. Australia, Comm. No. 1050/2002, CCPR/C/87/D/1050/2002 (2006); Human Rights Comm., Shafiq v. Australia, Comm. No. 1324/2004, CCPR/C/88/D/1324/2004 (2006); Human Rights Comm., Baban v. Australia, Comm. No. 1014/2001, CCPR/C/78/D/1014/2001 (2003); Human Rights Comm., Bakhtiyari v. Australia, Comm. No. 1069/2002, CCPR/C/79/D/1069/2002 (2003); Human Rights Comm., C. v. Australia, Comm. No. 900/1999, U.N. Doc. CCPR/C/76/D/900/1999 (2002). In spite of these views, Australia continues its practice of automatic detention. See Australian Human Rights Comm., Submission to the Joint Select Committee on Australia's Immigration Detention Network 11-27 (Aug. 2011), http://www.hreoc.gov.au/legal/submissions/2011/ 201108_immigration.html.

107. Human Rights Comm., Shafiq v. Australia, Commc'n No. 1324/2004, I 7.3, U.N. Doc. CCPR/C/88/D/1324/2004 (2006).

108. See Office of the United Nations High Comm'r, Alternatives to Detention of Asylum Seekers and Refugees, (Apr. 2006), www.unhcr.org/refworld/pdfid/4472e8b84.pdf (Ophelia Field \& Alice Edwards).

109. Human Rights Comm., C. v. Australia, Commc'n No. 900/1999, ๆ. 8.2, U.N. Doc. $\mathrm{CCPR} / \mathrm{C} / 76 / \mathrm{D} / 900 / 1999$ (2002).

110. Id.

111. Human Rights Comm., Jalloh v. Netherlands, Commc'n. No. 794/1998, If 8.2, U.N. Doc. CCPR/C/74/D/794/1998 (2002). 


\section{B. Refugee Convention}

The RC establishes a spectrum of rights allocated according to the degree of attachment between the refugee and the state in question. ${ }^{112}$ Article 26 on freedom of movement applies to those "lawfully in" the territory. ${ }^{113}$ While Article 26 clearly applies to recognized refugees, there is debate as to whether it applies to asylum seekers too. One view holds that Article 26 should apply to asylum seekers whose applications have been presented. ${ }^{114}$ In this view, then, asylum seekers should generally enjoy a right to free movement once formally in the asylum process, although their movement may be restricted under the same conditions as are "applicable to aliens generally in the same circumstances." 115 Notably, several European governments still contest the applicability of Article 26 to asylum seekers.116 Such contestation reflects a more general movement, whereby governments have distorted the scope of the $\mathrm{RC}$, by seeking to limit the rights attaching to the category of "asylum seeker." In contrast, the $\mathrm{RC}$ is based on the premise that asylum seekers are presumptive refugees, and to be treated accordingly, particularly in light of the declaratory character of refugee status. ${ }^{117}$

Article 31, the nonpenalization clause, is concerned with those who are illegally present in a state, provided that they "present themselves without delay to the authorities and show good cause for their illegal entry or presence." They are to be immune from penalties and subject only to such restrictions on free movement as are necessary. As to the meaning of "penalties," while some take the view that only criminal sanctions are precluded, ${ }^{118}$ several authoritative commentators take the

112. Hathaway describes this as the "structure of entitlement" under the RC. JAMES C. HATHAWAY, ThE Rights OF REFUgeEs UNDER INTERNATIONAL LAW 154 (2005). See GOODWIN-GILL, supra note 21, at 524-28, who described it as "criteria of entitlement."

113. The full text of the article states that "[e]ach Contracting State shall accord to refugees lawfully in its territory the right to choose their place of residence to move freely within its territory, subject to any regulations applicable to aliens generally in the same circumstances." RC, supra note 61 , art. 26.

114. See HATHAWAY, supra note 112 , at 173 , for extensive consideration of the meaning of "lawful stay."

115. RC, supra note 61, art. 26.

116. See Reinhard Marx, Article 26 (Freedom of Movement/Liberté de Circulation), in The 1951 Convention Relating to the Status of RefugeEs AND Its 1967 PRotocol: A COMMENTARY 1147, 1161-64 (Andreas Zimmermann et al. eds., 2011).

117. See Office of the United Nations High Comm'r, Handbook on Procedures and Criteria for Determining Refugee Status under the 1951 Convention and the 1967 Protocol Relating to the Status of Refugees, I 28, HCR/IP/4/Eng/REV.1 (1992) quoted in James Hathaway, What's in a Label?, 5 EUR. J. MIGRATION \& L. 1, 9-10 (2003).

118. Cornelisse simply asserts that "[i]t is not plausible that this provision would be violated when a refugee is detained on account of his illegal entry, if the deprivation of 
view that at least some forms of detention should be precluded as punitive. ${ }^{119}$ Alternatively, even if detention is not always regarded as a "penalty," Article 31(2) provides that the asylum seeker may be subjected only to such restrictions as are necessary. ${ }^{120}$

The UNHCR's Revised Guidelines on Detention of Asylum Seekers confirm that "[a]s a general principle, asylum-seekers should not be detained," and that detention is only permissible in exceptional circumstances, when it is reasonable, proportional, and necessary in order to attain a limited range of objectives. ${ }^{121}$ However the range of purposes is broad, allowing detention in order:

To verify identity; to determine the elements on which the claim to refugee status or asylum is based; to deal with cases where refugees or asylum-seekers have destroyed their travel and/or identity documents or have used fraudulent documents in order to mislead the authorities of the State in which they intend to claim asylum; or to protect national security or public order. ${ }^{122}$

The breadth of the grounds seems liable to undermine the commitment to ensuring that detention is an exceptional practice.

Regrettably, as Goodwin-Gill notes:

liberty is an administrative measure and is not categorized as a criminal sanction as such." CORNELISSE, supra note 15, at 262. She assumes that only Article 31(2) limits detention, requiring it to be "proportional in view of the individual circumstances of each and every individual." Id.

119. Guy Goodwin-Gill, Article 31 of the 1951 Convention Relating to the Status of Refugees: Non-penalization, Detention and Protection, in REFUGEE PROTECTION IN INTERNATIONAL LAW: UNHCR'S GLOBAL CONSULTATIONS ON INTERNATIONAL PROTECTION 185, 195-96 (Erika Feller, Volker Türk \& Frances Nicholson eds., 2003). See also EDWARDS, supra note 5, at 11 (citing Gregor Noll, Article 31 (Refuges Unlawfully in the Country of Refuget/Réfugés en Situation Irrégulière dans le Pays d'Accueil), in THE 1951 CONVENTION RELATING TO THE STATUS OF REFUgEeS AND ITS 1967 PROTOCOL: A COMMENTARY 1243, 1263-64 (Andreas Zimmermann et al. eds., 2011)).

120. Hathaway explains the "strictly provisional" nature of the detention power under Article 31(2), with Article 26 of the RC as the general provision applicable to most asylum seekers who have been admitted to the asylum procedure. HATHAWAY, supra note 112, at 414, 418-19. Hathaway also discusses "necessity." Id. at 423-39.

121. Office of the United Nations High Comm'r for Refugees, UNHCR's Guidelines on Applicable Criteria and Standards Relating to the Detention of Asylum-Seekers 3, (Feb. 1999), http://www.unhcr.org/refworld/docid/3c2b3f844.html.

122. Detention of Refugees and Asylum Seekers, Office of the United Nations High Comm'r for Refugees, 41st Sess., Jan. 13 1987, I 128(b), U.N. Doc. 12A (A/41/12/Add.1) (1987). 
Comparatively few states have taken any formal steps to incorporate the exemption from penalties required by Article 31 ... Even where legislative provisions exist, however, refugees and asylum seekers can still face loss of liberty. They are subject to the same law as is applied to non-nationals generally, and are thus exposed to prosecution, punishment, and/or detention, on account of illegal entry, entry without documents, or entry without falsified documents. ${ }^{123}$

His conclusion reflects the RC's relative lack of enforcement apparatus, as does the contestation over the scope of Article 26 of the RC.

\section{European Convention on Human Rights (ECHR)}

In contrast to the ICCPR, the ECHR enumerates a finite list of specific grounds of permitted detention, including two forms of immigration detention. ${ }^{124}$ Article 5(1)(f) permits detention "to prevent . . . unauthorised entry into the country" and "of a person against whom action is being taken with a view to deportation or extradition." ${ }^{25}$ Both

123. Goodwin-Gill, supra note 119 , at 226.

124. Article 5(1) provides:

No one shall be deprived of his liberty save in the following cases and in accordance with a procedure prescribed by law:

(a) the lawful detention of a person after conviction by a competent court;

(b) the lawful arrest or detention of a person for non-compliance with the lawful order of a court or in order to secure the fulfilment of any obligation prescribed by law;

(c) the lawful arrest or detention of a person effected for the purpose of bringing him before the competent legal authority of reasonable suspicion of having committed and offence or when it is reasonably considered necessary to prevent his committing an offence or fleeing after having done so;

(d) the detention of a minor by lawful order for the purpose of educational supervision or his lawful detention for the purpose of bringing him before the competent legal authority;

(e) the lawful detention of persons for the prevention of the spreading of infectious diseases, of persons of unsound mind, alcoholics or drug addicts, or vagrants;

(f) the lawful arrest or detention of a person to prevent his effecting an unauthorized entry into the country or of a person against whom action is being taken with a view to deportation or extradition.

European Convention on Human Rights, supra note 6, art. 5(1).

125. Id. 
forms of detention must be "in accordance with a procedure prescribed by law." 126

\section{The Requirement of Legality}

The requirement of legality, as is commonly the case under the ECHR, refers not only to conformity with enacted domestic law, but also entails rule of law criteria, particularly relating to the accessibility, precision, and foreseeability of the standards and procedures governing detention. ${ }^{127}$ On occasion, the requirement of legality encompasses more general concerns relating to detention conditions, such as when detention of vulnerable individuals or children is at issue.128 "In accordance with law" has a further, somewhat latent significance under the ECHR: where the state has additional obligations under EU law and potentially other international legal norms, these are liable to be incorporated into the notion of "in accordance with law." 129 Accordingly, there is much potential to read other legal standards into the ECtHR's rule of law conception.

The ECtHR frequently finds violations of Article 5(1) for lack of adherence to rule of law criteria. ${ }^{130}$ Some cases concern egregious breaches of domestic law: in Riad \& Idiab v. Belgium, the respondent state kept the applicants in detention despite two domestic court rulings to release them, rendering the detention unlawful under the

126. Articles 5(4) and (5) set out the right to have the lawfulness of detention tested "speedily by a court" and to compensation for unlawful detention, respectively. ECHR, supra note 4, art. 5(4)-(5). The procedural safeguard in Article 5(3) applies to those arrested or detained under Article 5(1)(c), but not to those detained under Article 5(1)(f).

European Convention on Human Rights, supra note 6, art. 5(3).

127. Amuur v. France, App. No. 19776/92, 22 Eur. H.R. Rep. 533, 559 (1996).

128. See Muskhadzhiyeva v. Belgium, App. No. 41442/07 Eur. Ct. H.R. (2010), http://www.echr.coe.int/echr/en/hudoc (follow "HUDOC database" hyperlink; search "Application Number 41442/07"). Mayeka v. Belgium, App. No. 13178/03 Eur. Ct. H.R. (2006), http://www.echr.coe.int/echr/en/hudoc (follow "HUDOC database" hyperlink; search "Application Number 13178/03").

129. In Mendizabal v. France, the ECtHR treated the EU right of residence of a Spanish national in France as an aspect of its Article $8 \mathrm{ECHR}$ legal patrimony. Mendizabal v. France, App. No. 51431/99, 50 Eur. H.R. Rep. 50 (2006).

130. See Al-Agha v. Romania, App. No. $40933 / 02$ Eur. Ct. H.R. (2010), http://www.echr.coe.int/echr/en/hudoc (follow "HUDOC database" hyperlink; search "Application Number 40933/02"); Soldatenko v. Ukraine, App. No. 2440/07 Eur. Ct. H.R. (2008), http://www.echr.coe.int/echr/en/hudoc (follow "HUDOC database" hyperlink; search "Application Number 2440/07"); John v. Greece, App. No. 199/05 Eur. Ct. H.R. (2007), http://www.echr.coe.int/echr/en/hudoc (follow "HUDOC database" hyperlink; search "Application Number 199/05"); Shamsa v. Poland, App. No. 45355/99 Eur. Ct. H.R. (2003), http://www.echr.coe.int/echr/en/hudoc (follow "HUDOC database" hyperlink; search "Application Number 45355/99"). 
ECHR also. ${ }^{131}$ The ECtHR has found repeated serious infractions of the requirement of legality by Turkey, ${ }^{132}$ Malta, ${ }^{133}$ and Russia. ${ }^{134}$ The ECtHR also scrutinizes conformity with domestic law with increasing intensity, at times effectively finding that the domestic courts have

131. Riad v. Belgium, App. No. 29787/03 Eur. Ct. H.R. at 74-76 (2008), http://www.echr.coe.int/echr/en/hudoc (follow "HUDOC database" hyperlink; search "Application Number 29787/03").

132. See Dbouba v. Turkey, App. No. 15916/09 Eur. Ct. H.R. (2010), http://www.echr.coe.int/echr/en/hudoc (follow "HUDOC database" hyperlink; search "Application Number 15916/09"); Tehrani v. Turkey, App. No. 32940/08 Eur. Ct. H.R. (2010), http://www.echr.coe.int/echr/en/hudoc (follow "HUDOC database" hyperlink; search "Application Number 32940/08"); Z.N.S. v. Turkey, App. No. 21896/08 Eur. Ct. H.R. (2010), http://www.echr.coe.int/echr/en/hudoc (follow "HUDOC database" hyperlink; search "Application Number 21896/08"); Abdolkhani v. Turkey, App. No. 30471/08 Eur. Ct. H.R. (2009), http://www.echr.coe.int/echr/en/hudoc (follow "HUDOC database" hyperlink; search "Application Number 30471/08"). Researcher Michael Flynn reports that "Turkey has refused to acknowledge, despite successive legal rulings against it, that its systematic confinement of irregular migrants in so-called guesthouses amounts to deprivation of liberty." Michael Flynn, Immigration Detention and Proportionality 8 (Global Detention Project, Working Paper No. 4, 2001), available at http://www.globaldetentionproject.org/ fileadmin/publications/GDP_detention_and_proportionality_workingpaper.pdf.

133. See Massoud v. Malta, App. No. 24340/08 Eur. Ct. H.R. (2010), http://www.echr.coe.int/echr/en/hudoc (follow "HUDOC database" hyperlink; search "Application Number 24340/08"); Kadem v. Malta, App. No. 55263/00 Eur. Ct. H.R. (2003), http://www.echr.coe.int/echr/en/hudoc (follow "HUDOC database" hyperlink; search "Application Number 55263/00"); Ali v. Malta, App. No. 35892/97 Eur. Ct. H.R. (2000), http://www.echr.coe.int/echr/en/hudoc (follow "HUDOC database" hyperlink; search "Application Number 35892/97"). Malta persists in automatically detaining asylum seekers, notwithstanding these rulings. See Report by Thomas Hammarberg, Commissioner for Human Rights of the Council of Europe, Following His Visit to Malta from 23 to 25 March 2011, CommDH(2011)17 (2011), https://wcd.coe.int/wcd/ ViewDoc.jsp?id=1797917 (prepared by Thomas Hammarberg).

134. See Sultanov v. Russia, App. No. 15303/09 Eur. Ct. H.R. (2010), http://www.echr.coe.int/echr/en/hudoc (follow "HUDOC database" hyperlink; search "Application Number 15303/09"); Iskandarov v. Russia, App. No. 17185/05 Eur. Ct. H.R. (2010), http://www.echr.coe.int/echr/en/hudoc (follow "HUDOC database" hyperlink; search "Application Number 17185/05"); Yuldashev v. Russia, App. No. 1248/09 Eur. Ct. H.R. (2010), http://www.echr.coe.int/echr/en/hudoc (follow "HUDOC database" hyperlink; search "Application Number 1248/09"); Isakov v. Russia, App. No. 14049/08 Eur. Ct. H.R. (2010), http://www.echr.coe.int/echr/en/hudoc (follow "HUDOC database" hyperlink; search "Application Number 14049/08"); Nolan v. Russia, App. No. 2512/04 Eur. Ct. H.R. (2009), http://www.echr.coe.int/echr/en/hudoc (follow "HUDOC database" hyperlink; search "Application Number 2512/04"); Muminov v. Russia, App. No. 42502/06 Eur. Ct. H.R. (2008), http://www.echr.coe.int/echr/en/hudoc (follow "HUDOC database" hyperlink; search "Application Number 42502/06"); Nasrulloyev v. Russia, App. No. 656/06 Eur. Ct. H.R. (2007), http://www.echr.coe.int/echr/en/hudoc (follow "HUDOC database" hyperlink; search "Application Number 656/06"); Garabayev v. Russia, App. No. 38411/02 Eur. Ct. H.R. (2007), http://www.echr.coe.int/echr/en/hudoc (follow "HUDOC database" hyperlink; search "Application Number 38411/02"). 
erred in their application of domestic law. In Rusu v. Austria, ${ }^{135}$ the Court ensured strict adherence with the necessity test in the applicable domestic law, although the Court does not incorporate this standard into its own requirements for Article 5(1)(f) detention. ${ }^{136}$ Other cases push the notion of "lawfulness" even further. For instance, in a case in which the decision to detain was ostensibly based on national security concerns, the Court deemed the detention to be unlawful as no specific allegations or charges were brought against the applicants, nothwithstanding that the detention was authorized under published law. ${ }^{137}$ In Lokpo \& Touré $v$. Hungary, ${ }^{138}$ the detention of asylum seekers was deemed unlawful due to the authority's failure to make a reasoned decision to continue detention: mere acquiescence ("non-action" 139 or "mere silence"140) in the continued detention was deemed insufficient to meet the requirement of legality. ${ }^{141}$ Although the legislation in question was adopted to give effect to the EU PD, the ECtHR did not take the opportunity to condemn the detention as unlawful, even though it appeared to violate the EU measure's

135. Rusu v. Austria, App. No. 34082/02, I 48 Eur. Ct. H.R (2008), http://www.echr.coe.int/ echr/en/hudoc (follow "HUDOC database" hyperlink; search "Application Number 34082/02"). For a discussion, see MOLE \& MEREDITH, supra note 63, at 158-61. For an intense review of the application of domestic law, see Jusic v. Switzerland, App. No. 4691/06 Eur. Ct. H.R. (2010), http:/www.echr.coe.int/echr/en/hudoc (follow "HUDOC database" hyperlink; search "Application Number 4691/06").

136. See infra Part II.C.2.

137. See Al-Agha v. Romania, App. No. 40933/02 Eur. Ct. H. R. (2010), http:// www.echr.coe.int/echr/en/hudoc (follow "HUDOC database" hyperlink; search "Application Number 40933/02"); Ahmed v. Romania, App. No. 34621/03 Eur. Ct. H.R. (2010), http://www.echr.coe.int/echr/en/hudoc (follow "HUDOC database" hyperlink; search "Application Number 34621/03"). In both rulings, the Court emphasized that national security grounds needed particular safeguards against abuse, in particular to ensure effective judicial protection, lest "sous le couvert de défendre la démocratie, de telles mesures risquent de la saper, voire de la détruire." Al-Agha, | 90 ("under the guise of defending democracy, these measures risk undermining it, even destroying it"); see also Ahmed, 1 33, (quoting Rotaru v. Romania, App. No. 28341/95 Eur. Ct. H.R. (2000), http://www.echr.coe.int/echr/en/hudoc (follow "HUDOC database" hyperlink; search "Application Number 28341/95")).

138. Lokpo v. Hungary, App. No. 10816/10, I 16-24 Eur. Ct. H.R. (2011), http://www.echr.coe.int/echr/en/hudoc (follow "HUDOC database" hyperlink; search "Application Number 10816/10").

139. Id. para 23.

140. Id. para 24.

141. But cf. id. (Jočienè \& Björgvinsson, J., dissenting) (arguing that the Court had strayed too far into the interpretation of national law, and that the continued detention should be assumed to be on the same grounds as the initial one-and if there was a deficit of judicial scrutiny, this might have been raised as an issue under Article 5(4) ECHR but had not been). 
requirement that detention not be for the "sole reason"142 that the applicants were asylum seekers.

\section{Predeportation Detention-the Rejection of a Test of 'Reasonable Necessity'}

The leading case on predeportation detention is Chahal v. U.K.143 The Court stated in Chahal, and has reiterated since, that Article 5(1)(f) "does not demand that the detention of a person against whom action is being taken with a view to deportation be reasonably considered necessary, for example to prevent his committing an offence or fleeing." 144 The only requirement was that the individual face deportation. Whether the underlying decision to expel could be justified under national or ECHR law was also deemed immaterial for the purposes of Article 5(1)(f). ${ }^{145}$ Having rejected the criterion of "reasonable necessity," the Court asserted that detention was only lawful as long as deportation proceedings were in progress and prosecuted with "due diligence."146 Strikingly, the Court held that detention while the asylum claim was still being assessed fell under Article 5(1)(f).147 By thirteen votes to six, it found no violation of Article 5(1), but unanimously found a violation of Article 5(4), as the domestic courts were unable to conduct a proper review due to the national security constraints on them.

The Court is increasingly insistent that states demonstrate that deportation must be a realistic prospect. If removal is not feasible due to the absence of travel documents, for example, detention will not be justified. ${ }^{148}$ The most recent Grand Chamber ruling on this matter, $A$. \& Others $v$. U.K., ${ }^{149}$ concerned the detention of foreign terrorist suspects. The Court accepted that they were nonremovable under the ECHR

142. PD, supra note 8 , art. $18(1)$.

143. Chahal v. United Kingdom, App. No. 22414/93, 23 Eur. H.R. Rep. 413 (1997).

144. Id. para. 112.

145. Id.

146. See id. para. 113; see also Quinn v. France, App. No. 18580/91, 21 Eur. H.R. Rep. 529, para. 48 (1995); Singh v. Czech Republic, App. No. 60538/00, para. 61 Eur. Ct. H.R. (2005), (follow "HUDOC database" hyperlink; search "Application Number 60538/00") (offering more recent applications of "due diligence" criterion).

147. See Chahal paras. 115-16.

148. See Ali v. Switzerland, App. No. 24881/94, 28 Eur. H.R. Rep. 304, para. 12 (1998); see also Mikolenko v. Estonia, App. No. 10664/05, para. 10 Eur. Ct. H.R. (2009), http://www.echr.coe.int/echr/en/hudoc (follow "HUDOC database" hyperlink; search "Application Number 10664/05"); Raza v. Bulgaria, App. No. 31465/08, paras. 11, 16 Eur. Ct. H.R. (2010), http:/www.echr.coe.int/echr/en/hudoc (follow "HUDOC database" hyperlink; search "Application Number 31465/08").

149. A. v. United Kingdom, App. No. $3455 / 05$ Eur. Ct. H.R. (2009) http://www.echr.coe.int/ echr/en/hudoc (follow "HUDOC database" hyperlink; search "Application Number 3455/05"). 
standards, due to human rights concerns in their countries of origin. Nonetheless, the United Kingdom sought to justify their detention under Article 5(1)(f) as it was keeping the possibility of removal "under active review." 150 The Court rejected the United Kingdom's argument, as this review was not "sufficiently certain or determinative to amount to 'action . . . being taken with a view to deportation."151 The Grand Chamber distinguished Chahal, stating that the earlier case proceedings were being "actively and diligently pursued" in order to determine whether removal would violate Article 3 of the ECHR. ${ }^{152}$ In contrast, in $A \&$ Others, the proceedings concerned the legality of detention, the prohibition of deportation having been conceded. ${ }^{153}$

The position of asylum seekers is precarious. It is arguable that in order to comply with the RC's and the ECtHR non-refoulement guarantees, they cannot be removed until their claims have been fully examined, and so should be regarded as temporarily lawfully present. Where domestic law reflects this position, the Court has held that asylum seekers are not lawfully in predeportation detention, as is seen in S.D. v. Greece and R.U. v. Greece. ${ }^{154}$ These cases are in tension with Chahal because, in the earlier case, the period in detention as an asylum seeker was deemed to be lawful predeportation detention. ${ }^{155}$ As yet, as discussed in the next section, the Court has shied away from insisting that, as a matter of ECHR law, asylum seekers are not in predeportation detention, as they are temporarily authorized entrants.

\section{Deportation to Prevent Unauthorized Entry: Statism Writ Large}

Article 5(1)(f) also permits detention to prevent unauthorized entry. The leading case is Saadi v. U.K. ${ }^{156}$ The applicant was an Iraqi doctor

150. Id. para. 167.

151. Id.

152. See id. para. 169.

153. See id. paras. 169-70.

154. See S.D. v. Greece, App. No. 53541/07, para. 62 Eur. Ct. H.R. (2009), http:// www.echr.coe.int/echr/en/hudoc (follow "HUDOC database" hyperlink; search "Application Number 53541/07") (referring specifically to the fact that national law precluded detention unless the deportation was executable); see also R.U. v. Greece, App. No. 2237/08, paras. 95-96 Eur. Ct. H.R. (2011), http:/www.echr.coe.int/echr/en/hudoc (follow "HUDOC database" hyperlink; search "Application Number 2237/08") (noting that both national law and the RC prevented removal and that, accordingly, the detention was not lawful under domestic law).

155. See also Lokpo v. Hungary, App. No. 10816/10, para. 16 Eur. Ct. H.R. (2011), http://www.echr.coe.int/echr/en/hudoc (follow "HUDOC database" hyperlink; search "Application Number 10816/10") (noting that it was common ground between the parties that the applicants, although asylum seekers, were being detained with a view to deportation).

156. Saadi v. United Kingdom, App. No. 13229/03, 47 Eur. H.R. Rep. 17 (2008). See 
who claimed asylum on arrival to the United Kingdom at Heathrow Airport. At that point, he was temporarily released and requested to return to the airport immigration authorities. He complied with the request, and four days later was detained and transferred to a detention center. The real reason for detention, in fact the entire institutional rationale for the particular detention center, was to facilitate fast-track processing of claims. ${ }^{157}$

The central premise of the majority in the Grand Chamber was that detention of those whose entry had not been authorized was a "necessary adjunct" to "undeniable sovereign right to control aliens entry into and residence in their territory."158 This "necessary adjunct" imports the statist assumption into detention practices. The Court also imported Chahal's rejection of a necessity test. The next move in the reasoning places asylum seekers and other migrants in a legally naked position: until a state has formally authorized entry, "any entry [is] 'unauthorized."' 159 Accordingly, the detention of anyone seeking entry who did not yet have the requisite authorization fell under Article 5(1)(f). ${ }^{160}$ However, the Court was at pains to stress that the state did not dispose of an open-ended right to detain, and so it tailored four context-specific requirements to avoid arbitrariness. Detention must be (1) carried out in good faith; (2) closely connected to the purpose of preventing unauthorized entry of the person; (3) in an appropriate place and under appropriate conditions bearing in mind that detainee has not "committed criminal offences" but rather may have fled fearing for his life; and (4) the length of the detention should not exceed that reasonably required for the purpose pursued. ${ }^{161}$ Applying these criteria to the facts, the majority held that seven days in a "specifically adapted" place of detention was not arbitrary, in light of the difficult administrative problems that confronted the United Kingdom during the period in question. 162

generally Violeta Moreno Lax, Beyond SAADI v UK. The "Necessity" Requirement for Administrative Detention of Asylum Seekers in the EU, (Reflexive Governance in the Pub. Interest, Working Paper No. REFGOV-FR-31 2010), available at http://refgov.cpdr.ucl.ac.be/ ?go=publications\&dc=561a56161f4c3720ba64e53b6bf6ea61d4ee4a84; Helen O'Nions, No Right to Liberty: The Detention of Asylum Seekers for Administrative Convenience, 10 EUR. J. MigRATION \& L. 149 (2008).

157. See Saadi paras. 23-25.

158. See id. para. 64 (citing Amuur v. France, 22 Eur. H.R. Rep. 533, 556-57, para. 43 (1996); Chahal v. United Kingdom, 23 Eur. H.R. Rep. 413, 454-55, para. 73 (1996); Abdulaziz v. United Kingdom, 7 Eur. H.R. Rep. 471, 497-98, paras. $67-68$ (1985)).

159. See id. para. 65.

160. See id.

161. Id. para. 74 .

162. See id. para. 80. 
The partly dissenting opinion of Judges Rozakis, Tulkens, Kovler, Hajiyev, Spielmann, and Hirvelä set out powerful counterarguments, which urge greater fidelity to other IHRL standards. First, they noted that the majority failed to distinguish between different categories of migrants, subjecting them all to the "[s]tates' unlimited sovereignty." 163 The dissenters viewed the majority's treatment of detention as the adjunct of sovereign entry control as sitting "uncomfortably with the principle that asylum seekers who have presented a claim for international protection are ipso facto lawfully within the territory of a State ...."164 It should be noted that the majority and the minority cite the HRC for authority of this proposition. ${ }^{165}$ Dismissing the notion of a statist carte blanche to deem any entry unauthorized, they found that in the particular case it had "in no sense been established in the present case, as the applicant did not enter or attempt to enter the country unlawfully." 166 On this point, the dissenters are in a difficult position, because if they deem all asylum seekers to be lawful entrants in all circumstances, then the state has no power to detain them under Article 5(1)(f). In a deft move then, the suggestion is that asylum seekers be treated as having a purpose-specific temporary admission. Accordingly, while it is not permissible to detain "refugees on the sole ground that they have made a claim for asylum," where evidence exists that they may abscond before the claim is determined, then detention would be permissible. In contrast, the United Kingdom's detention of Saadi was explicitly for the purpose of making the asylum determination process more efficient. The dissenters deemed that rationale improper, in terms worth setting out in full:

[N]ot just in the context of asylum but also in other situations involving deprivation of liberty, to maintain that detention is in the interests of the person concerned appears to us an exceedingly dangerous stance to adopt. Furthermore, to contend in the present case that detention is in the interests not merely of the asylum seekers themselves "but of those increasingly in the queue" is equally unacceptable. In no circumstances can

163. See id. at para. 32 (Rozakis, Tulkens, Kovler, Hajiyev, Spielmann \& Hirvelä, J., dissenting).

164. Id. at para. 31.

165. See id. para. 32, 35 (citing U.N. Human Rights Comm., Celepli v. Sweden, Commc'n No. 456/1991, U.N. DoC. CCPR/C/51/D/456/1991 (1994).

166. See id. at para. 33 (Rozakis, Tulkens, Kovler, Hajiyev, Spielmann and Hirvelä, J., dissenting). 
the end justify the means; no person, no human being may be used as a means towards an end. 167

Under the majority's approach, the asylum seeker "becomes an object rather than a subject of law." 168

On the application of the test to the facts, they further questioned how to determine how long detention might last: If seven days was reasonable, "where and how do we draw the line for what is unacceptable?"169 The dissenters also took issue with the failure to examine alternatives to detention as part of the nonarbitrariness assessment. ${ }^{170}$

Of central interest for present purposes is the approach of the minority to IHRL more generally. The minority also noted that the ECHR "[does] not apply in a vacuum," 171 setting out the key HRC jurisprudence ${ }^{172}$ and EU norms, noting that Article 18(1) of the PD, precluding detention for the "sole reason" of being a refugee, should be regarded as "the minimum guarantee."173 On the majority's lack of fidelity to the other international standards, described as the "crux of the matter," the minority opinion ends with the following stinging rebuke:

Ultimately, are we now also to accept that Article 5 [of the ECHR], which has played a major role in ensuring controls of arbitrary detention, should afford a lower level of protection as regards asylum and immigration which, in social and human terms, are the most crucial issues facing us in the years to come? Is it a crime to be a foreigner? We do not think so.

The Council of Europe's Parliamentary Assembly criticized the Saadi judgment. First, the interpretation of "unauthorized entry" meant that the state could detain "ad infinitum." ${ }^{174}$ Secondly, it was in "blatant conflict" with the UNHCR guidelines on detention in allowing detention throughout the entire asylum process. ${ }^{175}$ The Parliamentary Assembly's

167. Id.

168. Id. at para. 34 .

169. See id.

170. See id.

171. Id.

172. See id. at paras. $34-35$.

173. See id. at para. 35 .

174. See MENDONÇA, supra note 2, at 19.

175. Id. 
Rapporteur called on the Court to reexamine its case law "taking fully into account other international sources of law and views of the international community."176

Since Saadi, the Court has come back to the issue of detention to prevent unauthorized entry only once, in Rusu v. Austria. ${ }^{177}$ As outlined above, in Rusu the detention was deemed arbitrary mainly due to the failure to adhere to the Austrian domestic legal standards, in particular its necessity test. However, the Court also emphasized that it was implausible on the facts to treat the applicant as attempting to effectuate an unauthorized entry, when she was in fact trying to leave Austria. This ruling may signal a more intense judicial review of both adherence to domestic standards and the factual matrix surrounding the claim of unauthorized entry. ${ }^{178}$

\section{Assessment of the Strasbourg Case Law}

Overall, the case law is predominantly concerned with legality criteria. Certainly, this preoccupation reflects in part the types of violations coming before the ECtHR, wherein states have internalized the statist assumption, and erroneously regarded their own prerogatives as not requiring legal authority in the normal sense. Yet, it also reflects a choice on the part of the ECtHR to emphasize the domestic protection of rights. However, without clear ECtHR review of the purposes and necessity of detention, domestic law and rule of law criteria may offer little protection in practice.

The two weak points in the Strasbourg case law are the approach to the determination of "unauthorized entry" and the loose nexus required between deportation and detention. On the former, the notion of the state's carte blanche to authorize entry is also ill fitting when legal authority is exercised at different levels. The RC, and the EU law giving effect to it, clearly envisages asylum seekers as temporarily authorized entrants, as are many other categories of individuals who enjoy rights of entry and residence under EU law. For a court of IHRL to ignore these obligations is to treat states as plenipotentiaries over a matter that they

176. Id. at 21 .

177. See Rusu v. Austria, App. No. 34082/02, 49 Eur. H.R. Rep. 28 (2009).

178. See MOLE \& MEREDITH, supra note 63, at 151 (pointing out that Rusu is a Chamber judgment delivered by seven judges, four of whom had been dissenters in Saadi v. United Kingdom, and two of whom had voted with the majority); see also CoRNELISSE, supra note 15 , at 312 (suggesting that this "one case" where the court closely analyzed the proportionality of the detention was striking in that it concerned "a person who was not at all 'out of place' in the global territorial ideal, but instead on her way back to the country where she 'belonged"). 
have already ceded discretion. Strasbourg moved in the right directive in R.U. v. Greece ${ }^{179}$ and S.D. v. Greece, ${ }^{180}$ but regrettably did not engage with the question of EU standards in Lokpo \& Touré $v$. Hungary. ${ }^{181}$

On the deportation-detention nexus, by rejecting the necessity test, the Court explicitly sets a lower standard of protection for immigration detention than for other forms. ${ }^{182}$ The "necessary adjunct" construct in fact allowed states to transplant the degree of discretion they (putatively) disposed of over admission to the territory to another domain, detention. It would be appropriate for the ECtHR to take a prompt from the HRC jurisprudence and EU norms, and read requirements of necessity and proportionality into Article 5(1)(f). Normally under the ECHR, rights restrictions must be proportionate, ${ }^{183}$ meaning that the restriction must be suitable to achieve the particular legitimate aim. Thus necessary and proportionate are used in the strict sense, which involves examining alternative less rights-intrusive means. Such is the "ubiquity of proportionality analysis" 184 that some defend as the central principle of human rights adjudication. ${ }^{185}$ Without necessarily endorsing that view, for the ECtHR to be textually faithful to Article 5, the ECHR requires it to insist on finite permissible grounds for detention. But the failure to insist on the appropriate demonstrable link between the detention in question and the ground in question (be it to effectuate deportation or to prevent unauthorized entry) undermines the textual commitment to limit detention to specified grounds.

179. R.U. v. Greece, App. No. 2237/08 Eur. Ct. H.R. (2011), http://www.echr.coe.int/ echr/en/hudoc (follow "HUDOC database" hyperlink; search "Application Number $2237 / 08 ")$.

180. S.D. v. Greece, App. No. 53541/07 Eur. Ct. H.R. (2011), http://www.echr.coe.int/ echr/en/hudoc (follow "HUDOC database" hyperlink; search "Application Number $\left.53541 / 07^{\prime \prime}\right)$.

181. Lokpo v. Hungary, App. No. 10816/10 Eur. Ct. H.R. (2011), http://www.echr.coe.int/ echr/en/hudoc (follow "HUDOC database" hyperlink; search "Application Number 10816/10").

182. See CORNELISSE, supra note 15, at 279, 305-08 (comparing case law under Article 5 (1)(e), which concerns "the lawful detention of persons for the prevention of the spreading of infectious diseases, of persons of unsound mind, alcoholics or drug addicts, or vagrants," with that of Article 5(1)(f)); see also CLARE OVEY \& ROBIN WHITE, JACOBS \& WHITE: EUROPEAN CONVENTION ON HUMAN RIGHTS 133 (2002).

183. European Convention on Human Rights, supra note 6, art. 8-11. Admittedly, there is often a textual basis, as the restrictions in question must be "necessary in a democratic society" under the relevant Treaty Article. However, the principle is built into the structure of analysis beyond those provisions as well.

184. Mattias Kumm, The Idea of Socratic Contestation and the Right to Justification: The Point of Rights-Based Proportionality Review, 4 LAW \& ETHICS HUM. RTS. 140, 142 (2010).

185. See DaVid BeatTy, The Ultimate Rule of Law 187 (2004). See generally RoberT ALEXY, A THEORY OF CONSTITUTIONAL RIGHTS (2002). 
Constructive human rights pluralism is evident in the minority opinion in Saadi. The minority opinion shows that appropriate engagement with the external standards of the HRC and RC, would have led to a different result. Strasbourg's failure to engage with the ICCPR standards in all of its immigration detention cases is striking. ${ }^{186}$

\section{EU Law}

The EU legislation governing immigration detention takes the form of directives. These are binding norms that envisage further legislative implementation by the Member States. ${ }^{187}$ However, once the implementation date prescribed has passed, individuals may invoke those provisions of the directive that are sufficiently clear and precise. ${ }^{188}$ This doctrine of direct effect allows individuals to invoke the unimplemented Directive against the state but not vice versa. ${ }^{189}$ Once an EU directive's implementation date has passed, individuals and their lawyers will have no hesitation to invoke those of its provisions that may be beneficial. ${ }^{190}$ This helps explain how even an apparently repressive measure like the $R D$, discussed below, produces cases that are protective of migrants' rights, at least when Member States are dilatory in implementation. Given EU law's strong normative punch,

186. See Ian Bryan \& Peter Langford, The Lawful Detention of Unauthorised Aliens Under the European System for the Protection of Human Rights, 80 NORDIC J. OF INT'L L. 193, 203-04 (2011).

187. See TFEU supra note 7, art. 228.

188. Case 41/74, Van Duyn v. Home Office, 1974 E.C.R. 1337 (describing the doctrine of "vertical direct effect").

189. The opinion of Advocate General Ruiz-Jarabo Colomer in Joined Cases C-152154/07, Arcor v. Germany, 2008 E.C.R. I-5959, para. 98 accurately captures the legal position:

The doctrine of direct effect operates on a vertical, one-way plane (from an individual to the State), in that traffic in the opposite direction (reverse vertical relationships) (citing Joined Cases C-74/95 and C$129 / 95 X, 1996$ E.C.R. I-6609) and perpendicular routes which would enable a directive to be relied on between individuals (horizontal direct effect) are both prohibited. (citing Case 152/84, Marshall v. Southampton and South-West Hampshire Area Health Authority, 1986 E.C.R. 723).

See also, Case C-61/11 PPU, Hassen El-Dridi alias Karim Soufi, 2011 ECJ EUR-Lex CELEX LEXIS 1027, para. 28 (Apr. 28, 2011) (view of Advocate General Jàn Mazák).

190. See, e.g., Serge Slama, Le Noël Des Sans-Papiers : invoquez directement la directive "retour" et la charte des droits fondamentaux..., COMBATS POUR LES DROITS DE L'HOMME (CPDH) BLOG (Dec. 26, 2010), http://combatsdroitshomme.blog.lemonde.fr/les-suites-dunoel-des-sans-papiers-invocabilite-de-la-directive-retour-du-16-decembre-2008-depuis-le24-decembre-2010/. The title "Le Noël des sans-papiers" (The Christmas of Undocumented Migrants) refers to the RD's implementation date of December 24, 2010. After that time, migrants could invoke the RD against the State. 
national governments that form part of the main EU legislative body are loath to commit to legislative norms that will constrain them excessively. Yet, the combination of terse laconic norms and strong judicial enforcement may have unanticipated consequences for national executives.

\section{Detention of Asylum Seekers}

Both the $\mathrm{RCD}^{191}$ and $\mathrm{PD}^{192}$ make references to detention. In addition, the EU is currently revising the Dublin Regulation to include detention rules. ${ }^{193}$ At present, the Regulation does not contain any provisions on detention, but in practice it is seen to have contributed to the increase in detention of asylum seekers across Europe, as it increases the cohort of asylum seekers who are amenable to removal before the claims have been processed. ${ }^{194}$

The original proposal for the RCD contained a detailed provision on detention, largely modeled on Executive Committee Conclusion Number 44. ${ }^{195}$ However, negotiating wrangles produced oblique, piecemeal provisions instead. Article 7 of the RCD provides that "[a]sylum seekers may move freely within the territory of the host Member States." However, Member States may decide on "the residence of the asylum seeker for reasons of public interest, public order, or, when necessary, for the swift processing and effective monitoring of his or her application."196 This provision seems to fall far short of Article 26 of the RC. ${ }^{197}$

191. RCD, supra note 9.

192. $\mathrm{PD}$, supra note 8. For analysis of both, see Dan Wilsher, Immigration Detention and the Common European Asylum Policy, in WHOSE FREEDOM, SECURITY AND JUSTICE?: EU IMMIGRATION AND ASYLUM LAW AND POLICY 395, 418-25 (Annelise Baldaccini et al. eds., 2007); Kay Hailbronner, Detention of Asylum Seekers 9 EUR. J. OF MIGRATION \& L. 159,169 (2007).

193. Council Regulation $343 / 2003$, supra note 47 . The recast proposal contains a new provision (Article 27) on detention. See Proposal for a Regulation of the European Parliament and of the Council Establishing the Criteria and Mechanisms for Determining the Member State Responsible for Examining an Application for International Protection Lodged in One of the Member States by a Third-Country National or a Stateless Person (Recast), at 48, COM (2008) 820 final (Mar. 12, 2008).

194. For some qualitative evidence, see Dublin II: A Summary of JRS Experiences in Europe, JESUIT REFUGEE SERV. (Oct. 2008), www.jrseurope.org/AdvocacyPages/ Dublin\%20Regulation/DublinSummaryJRSResponsesFinal.pdf.

195. See generally U.N. High Comm'r for Refugees, Exec. Comm., No. 44 Detention of Refugees and Asylum-Seekers (1986), http://www.unhcr.org/cgi-bin/texis/vtx/home/ opendocPDFViewer.html?docid=4aa 764389\&query=detention\%20of\%20refugees $\% 20$ and $\% 20$ asylum-seekers\%20no.\%2044; see also, Wilsher, supra note 192, at 422.

196. RCD, supra note 9, art. 7(2).

197. Marx, supra note 116, at 1163-64. 
On detention stricto sensu, Article 18(1) of the PD states plainly that detention should not be for the sole reason that the individual is an applicant for asylum. ${ }^{198}$ Article $7(3)$ of the RCD states that "[w]hen it proves necessary, for example for legal reasons or reasons of public order, Member States may confine an applicant to a particular place in accordance with their national law." 199 Here we find the necessity criterion that is absent in the Strasbourg case law. ${ }^{200}$ However, the guarantee is undermined by the vague open-ended grounds expressed as, "for example for legal reasons or reasons of public order." The vagueness of these grounds sits uneasily with the approach of the HRC, in particular. The border procedures provision in Article 15(4) of the PD seems to envisage confinement of asylum seekers at the border for a prolonged period of up to four weeks, detention in all but name.

The provisions are replete with transformative potential. The PD recognizes the right of the asylum seeker to be on the territory of the Member States. ${ }^{201}$ On this basis alone, it seems difficult for an EU Member State to treat asylum seekers' presence as unauthorized; at the very least the approach of the minority in Saadi would have to be applied. Similarly, asylum seekers could not be normally regarded as in predeportation detention, following the approach in R.U. v. Greece and S.D. $v$. Greece. ${ }^{202}$ The remaining leeway to detain asylum seekers is

198. Article 18 provides:

"1. Member States shall not hold a person in detention for the sole reason that he/she is an applicant for asylum. 2. Where an applicant for asylum is held in detention, Member States shall ensure that there is a possibility of speedy judicial review." PD, supra note 8, at 23.

199. RCD, supra note 9, art. 7(3).

200. See generally Lax, supra note 156.

201. See PD, supra note 8, at 18 ("Applicants shall be allowed to remain in the Member State, for the sole purpose of the procedure, until the determining authority has made a decision in accordance with the procedures at first instance set out in Chapter III. This right to remain shall not constitute an entitlement to a residence permit.") See also Council Directive 2008/115, 2008 O.J. (L 348) 98 (EC). ("In accordance with [the PD] a [TCN] who has applied for asylum in a Member State should not be regarded as staying illegally on the territory of that Member State until a negative decision on the application, or a decision ending his or her right of stay as asylum seeker has entered into force"). The PD appears to leave it to Member States to decide whether there is a right to remain pending resolution of any appeals or reviews of first instance decisions. However, the case law of the ECtHR requires suspensive effect of appeals to vindicate Articles 3 (where such risks pertain) and 13 ECHR. See Gebremedhin v France, App. No. 25389/05, I 34 Eur. Ct. H.R. (2007), http://www.echr.coe.int/echr/en/hudoc (follow "HUDOC database" hyperlink; search "Application Number 25389/05"). See also Thomas Spijkerboer, Subsidiarity and 'Arguability': The European Court of Human Rights' Case Law on Judicial Review in Asylum Cases 21 INT'L J. REFUGEE L. 48, 69-73 (2009).

202. See S.D. v. Greece, App. No. 53541/07 Eur. Ct. H.R. (2009), http://www.echr.coe.int/ echr/en/hudoc (follow "HUDOC database" hyperlink; search "Application Number 
accordingly diminished, and would require some infraction on the part of the individual asylum seeker in order to render her stay unauthorized. Even in that instance, the detention would need to be demonstrated as a necessary means to achieve the particular legitimate aim in view. Proportionality, encompassing the three elements of suitability, necessity, and least restrictive means, is a ubiquitous feature of EU law. ${ }^{203}$ The building blocks for a new, more rigorous adjudicatory framework are contained in these terse rules. Whether that potential is exploited depends largely on suitably crafted references from national courts coming before the CJEU.

\section{Predeportation Detention and the CJEU Kadzoev and El Dridi Rulings}

The RD sets out rules governing the conditions and procedures for the return (i.e., deportation) of illegal TCNs. ${ }^{204}$ Once a Member State deems someone "illegal" the RD sets out "a horizontal set of rules, applicable to all [TCNs] who do not or who no longer fulfill the conditions for entry, stay or residence in a Member State."205 Like the asylum directives, it took prolonged negotiations to reach agreement on the RD, though involving the European Parliament as a colegislator. ${ }^{206}$ Some of the standards in the RD are lamentably low, prompting a broad-based international campaign against its adoption, during which

53541/07"); see also R.U. v. Greece, App. No. 2237/08 Eur. Ct. H.R. (2011), http://www.echr.coe.int/echr/en/hudoc (follow "HUDOC database" hyperlink; search "Application Number 2237/08").

203. Proportionality is a general principle of EU law. In addition, the EUCFR contains a general limitation clause in Article 52(1). See Charter of Fundamental Rights of the European Union, supra note 57, art. 52(1) (stating, "Any limitation on the exercise of the rights and freedoms recognised by this Charter must be provided for by law and respect the essence of those rights and freedoms. Subject to the principle of proportionality, limitations may be made only if they are necessary and genuinely meet objectives of general interest recognised by the Union or the need to protect the rights and freedoms of others" (emphasis added)).

204. For detailed analysis, see Anneliese Baldaccini, The Return and Removal of Irregular Migrants Under EU Law: An Analysis of the Returns Directive, 11 EUR. J. MIGRATION \& L. 1 (2009). See also Anneliese Baldaccini, The EU Directive on Return: Principles and Protest, 28 Refugee SURV. Q. 114 (2010); Martin Schieffer, Chapter V. Termination of Residence, in EU IMMIGRATION AND ASYLUM LAW: COMMENTARY ON EU REGULATIONS AND DiRECTIVES (Kai Hailbronner ed., 2010).

205. Council Directive 2008/115, supra note 201, at 98.

206. See generally Diego Acosta, The Good, the Bad and the Ugly in EU Migration Law: Is the European Parliament Becoming Bad and Ugly?, 11 EUR. J. MIGRATION \& L. 19 (2009) (discussing the different steps in the adoption of the Directive); see also FABIAN LuTZ, THE NEgotiations ON THE RETURN DIRECTIVE: COMMENTS AND MATERIAIS (2010). 
it was condemned as a "shameful" and "outrageous" measure. 207 The eighteen-month outer time limit for detention has been the focus of the most criticism. ${ }^{208}$ While Member States are not obliged to permit such long detention, in practice several have increased detention times in implementing the Directive. ${ }^{209}$ Further, reentry bans reinforce the impression of a repressive measure. ${ }^{210}$

Yet, the RD integrates human rights principles, ${ }^{211}$ in particular the principle of proportionality. ${ }^{212}$ It aims to encourage voluntary return, so the coercive moves to detain and deport may only be engaged after a waiting period. 213 The preamble cites the Council of Europe's Twenty Guidelines on Forced Return. ${ }^{214}$ Concerning detention, Recital 16 provides:

207. See, e.g., No to the Outrageous Directive, www.statewatch.org/news/2007/dec/eureturns-ngo-compilation.pdf (document prepared by 14 European pro-migrant NGOs, subsequently supported by 400 European organizations and more than 8,000 citizens); see also Press Release, European Council on Refugees and Exiles (ECRE), Returns Directive: EU Fails to Uphold Human Rights (June 18, 2008), http://www.ecre.org/files/ ECRE\%20press\%20release\%20Returns\%20Dir.pdf; U.N. High Comm'r. for Refugees, UNHCR Position on the Proposal for a Directive on Common Standards and Procedures in Member States for Returning Mlegally Staying Third-Country Nationals (June 16, 2008), http://www.unhcr.org/refworld/pdfid/4856322c2.pdf; Press Release UN Experts Express Concern About Proposed EU Return Directive, UN Press Release (July 18, 2008).

208. See, e.g., Eur. PARL. ASS. DEB. 7th Sess. para. 5 (Jan. 28, 2010) ("The European Union Return Directive, which provides for a maximum length of detention for irregular migrants of up to eighteen months, can be criticised for adopting the lowest common standard with regard to length of detention . . . and increasing the possibility for states to increase their minimum duration of detention."). See generally Report of the Working Group on Arbitrary Detention, U.N. Doc. A/HRC/13/30 (Jan. 18, 2010).

209. See Michael Flynn \& Cecilia Cannon, Detention at the Borders of Europe: Report on the Joint Global Detention Project, Global Detention Project, Oct. 2-3, 2010, at 5. (stating "Greece, Italy, and Spain have all increased detention times since adopting the Return Directive. A fourth country, Hungary, is set to double maximum detention terms when newly adopted legislation enters into force at the end of 2010"). For a detailed overview of detention time limits, see Fundamental Rights Agency, supra note 97, at 3135. On implementation more generally, see THE RETURNS DIRECTIVE: CENTRAL THEMES, PROBLEM IsSUES, AND IMPLEMENTATION IN SELECTED MEMBER STATES (Karin Zwaan ed., 2011).

210. See generally Council Directive 2008/115, supra note 201, art. 11. (explaining the issuing of entry bans).

211. See id. at Recital 2 (referring to "full respect for ... fundamental rights and dignity"); see also id. at Recital 24 (asserting that "[t]his Directive respects the fundamental rights and observes the principles recognised in particular by the Charter of Fundamental Rights of the European Union.").

212. See id. at Recitals $13,16$.

213. See id. at Recital 10, art. 7. The period envisaged is between seven and thirty days.

214. Id. at Recital 3. Twenty Guidelines on Forced Return, supra note 94. On many contentious issues in the negotiations, the Twenty Guidelines provided compromise solutions. See Schieffer, supra note 204, at 1506. 
The use of detention for the purpose of removal should be limited and subject to the principle of proportionality with regard to the means used and objectives pursued. Detention is justified only to prepare the return or carry out the removal process and if the application of less coercive measures would not be sufficient.

Article 15 requires that detention only be used as a last resort, for as short a period as possible, with the specific purpose of preparing and carrying out the return process and crucially for as long as it is "necessary to ensure successful removal."215 Two specific purposes are given as examples of when detention would be necessary: when there is a risk of absconding, or when the individual concerned avoids or hampers the preparation of return or of the removal process. Reflective of the ECtHR case law, detention is only permissible "as long as removal arrangements are in progress and executed with due diligence." 216 In the absence of a "reasonable prospect of removal," detention must cease. Article 15's terms are clearly stricter than the ECtHR case law in incorporating a necessity requirement.

The CJEU has given two rulings on the legality of predeportation detention under the RD, Kadzoev, ${ }^{217}$ and $E l$-Dridi, ${ }^{218}$ both under its new urgent preliminary reference procedure. ${ }^{219}$

\section{a. Kadzoev 220}

Kadzoev's prolonged detention in Bulgaria shows the sharp end of EU detention practices. ${ }^{221}$ At the time of the references, he had spent

215. Council Directive 2008/115, supra note 201, art. 15.

216. Id. art. 15(1).

217. Case C-357/09 PPU, Kadzoev, 2009 E.C.R. I-11189.

218. See Case C-61/11 PPU, Hassen El-Dridi alias Karim Soufi, 2011 ECJ EUR-Lex CELEX LEXIS 1027 (Apr. 28, 2011).

219. See TFEU, supra note 7, art. 267 (stating, "[i]f such a question is raised in a case pending before a court or tribunal of a Member State with regard to a person in custody, the Court of Justice of the European Union shall act with the minimum of delay"); see also Consolidated Version of the Rules of Procedure of the Court of Justice (CJEU), art. 104b, 2010 O.J. (C 177) 1, 28. For a general discussion, see Catherine Barnard, The PPU: Is it Worth the Candle? An Early Assessment, 34 EUR. L. REv. 281 (2009).

220. See generally Elitsa Mincheva, Case Report on Kadzoev, 30 November 2009, 12 EUR. J. Migration \& L. 361 (2010) (detailing the Kadzoev case).

221. Concerning Kadzoev's particular case, see Fear of Forcible Return/Fear of Torture or Ill-Treatment, AMNESTY INT'L (Apr. 18, 2008), http://amnesty.org/en/library/asset/EUR15/ 001/2008/en/90cd1485-0d65-11dd-a114-e974a1f25b3e/eur150012008eng.pdf. See also Report of the Special Rapporteur on Torture and Other Cruel, Inhuman or Degrading Treatment or Punishment, 42-43, U.N. Doc. A/HRC/10/44/Add4 (Feb. 17, 2009) (by Manfred Nowak). 
thirty-four months in detention, despite bringing unsuccessful asylum claims and judicial reviews in order to secure his release. The reference arose when the domestic court was seized by a request from the Directorate for Migration at the Ministry of the Interior requesting it to rule ex officio on the legality of the duration of detention. The questions referred concerned the temporal and material scope of Article 15 of the $\mathrm{RD}$ in light of the particular facts of the case. The first two questions concerned the determination of which periods were covered by the prescribed maximum detention period. The first question concerned periods predating the Directive's entry into force, while the second question raised the crucial question of how the periods while asylum applications were pending should be regarded. The third question concerned periods when the execution of the removal was suspended pending appeal. The fourth question went to the meaning of removal being "reasonably possible," raising fact-specific concerns pertaining to the noncooperation of the Russian authorities. The fifth and final question asked what the Bulgarian authorities were to do if the maximum detention period had passed and "there [was still] a doubt as to [the applicant's] identity, he [was] aggressive in his conduct, he [had] no means of supporting himself and there [was] no third person who has undertaken to provide for his subsistence?"222

The specific answers may be summarized quickly: the period spent in detention prior to the entry into force of the RD did count toward the maximum period, when proceedings were ongoing after its entry into force. ${ }^{223}$ Periods spent as an asylum seeker did not count toward the period, as a separate regime addressed this issue, and, crucially, asylum seekers were not "illegal," so they did not fall under the RD. If, however, no specific decision had been taken to detain Kadzoev under the asylum rules, the time under the RD would continue to run. ${ }^{224}$ Similarly, periods in detention when deportation was suspended pending appeal did count toward the RD time limit. 225 The "reasonable prospect of removal" meant a realistic prospect, which would not pertain if the receiving country was unlikely to admit the individual within a "reasonable period" (according to the Advocate General (AG)) ${ }^{226}$ or the period set out in the RD (according to the Court). ${ }^{227}$ Once the detention

Concerning detention practices in general in Bulgaria, see Valeria Ilareva, Bulgaria's Treatment of Asylum Seekers, 29 FORCED MIGRATION REV. 60 (2007), available at www.fmreview.org/FMRpdfs/FMR29/60-61.pdf.

222. Case C-357/09 PPU, Kadzoev, 2009 E.C.R. I-11189, para. 30.

223. Id. paras. 34-39.

224. Id. paras. 40-48.

225. Id. paras. 49-57.

226. Id. paras. $65-66$.

227. Id. 
period was up, there was no further basis to detain the individual under EU law, and immediate release was required, ${ }^{228}$ notwithstanding the facts the Bulgarian government sought to rely on. ${ }^{229}$ In a footnote, the AG acknowledged the possibility of residual Member State competence to detain "because of aggressive behaviour on the basis of national legislation intended to maintain public order or the criminal law, for example." 230 The Court was silent on this crucial question of the extent to which Member State action had been preempted by the RD.

\section{b. El-Dridi}

El-Dridi ${ }^{231}$ delves even more deeply into the immigration detention practices of the Member State concerned, Italy, and raises precisely those preemption questions that were left unanswered in Kadzoev.

Italy has been at the forefront of the criminalization of irregular migration, a trend seen increasingly across Europe. ${ }^{232}$ Detention for committing a crime is conceptually and legally distinct from immigration detention, as Article 5 of the ECHR reflects. However, immigrant populations increasingly fall foul of criminal laws specifically designed to criminalize their presence. In Italy, it is a criminal offense for a foreigner to remain in the country once a legal order to leave the territory has been issued. ${ }^{233}$ Although the Italian Constitutional Court has tempered the strictness of the offense, the crime of illegal presence remains. ${ }^{234}$ Notably, the Italian Constitutional Court has recently issued a number of rulings undermining some elements of the repressive anti-immigrant legislation, known as the "security package."235 El-Dridi may be viewed as part of this process of judicial

228. Id. paras. 68-71.

229. Id. para. 71 .

230. Id., n.38 (view of Advocate General Jàn Mazák). See also Galina Cornelisse, Casenote on C-357/O9 PPU, 48 COMMON MKT. L. REV. 925, 933 (2011).

231. See Case C-61/11 PPU, Hassen El-Dridi alias Karim Soufi, 2011 ECJ EUR-Lex LEXIS 1027 (Apr. 28, 2011).

232. See generally Council of Eur.: Comm'r for Human Rights, Criminalisation of Migration in Europe: Human Rights Implications (Feb. 4, 2010), available at http://www.unhcr.org/refworld/docid/4b6a9fef2.html.

233. See El-Dridi, 2011 ECJ EUR-Lex LEXIS 1027, para. 17 for the full text of the synopsized provisions.

234. See Report of the WGAD, supra note 91, ๆ $57-67$ for an extensive discussion of both Italy's "extraordinary measures in the fight against crime by irregular migrants" and immigration detention stricto sensu. The Italian Constitutional Court has reviewed this law, and precluded its application in cases where noncompliance with the order to leave was justified. See Cass., sez. un., 17 dicembre 2010, n. 359, (It.) (Case No. 359/2010).

235. All, bar one (Case C-144/11, Abdallah, 2011 O.J. (C 152) 17), have been terminated in light of El-Dridi (see YASHA MACCANICO, STATEWATCH ANALYSIS: ITALY - SERIES OF 
action to constrain the states' immigration decrees. Italian judges sent a raft of similar preliminary references on the topic. ${ }^{236}$ The questions referred merit setting out in full:

In the light of the principle of sincere cooperation, the purpose of which is to ensure the attainment of the objectives of the directive, and the principle that the penalty must be proportionate, appropriate and reasonable, do Articles 15 and 16 [RD] preclude:

-the possibility that criminal penalties may be imposed in respect of a breach of an intermediate stage in the administrative return procedure, before that procedure is completed, by having recourse to the most severe administrative measure of constraint which remains available?

-the possibility of a sentence of up to four years' imprisonment being imposed in respect of a simple failure to cooperate in the deportation procedure on the part of the person concerned, in particular where the first removal order issued by the administrative authorities has not been complied with?237

DEFEATS IN COURT FOR THE "SECURITY PACKAGE" (Statewatch, 2011), available at www.statewatch.org/analyses/no-137-italy-security-package.pdf). See generally Italian Constitutional Court, 25 July 2011, No. 245 (striking down a law restricting the right to marry of irregular migrants); Italian Constitutional Court, 8 July 2010, No. 249 (striking down a law imposing additional criminal penalties on irregular migrants); Italian Constitutional Court, 4 Apr. 2011, Case No. 115 (striking down a law conferring excessive powers on local government to combat irregular migration), available at http://www.cortecostituzionale.it/actionPronuncia.do.

236. See Case C-43/11, Assane Samb, 2011 O.J. (C 113) 7; Case C-50/11, Lucky Emegor, 2011 O.J. (C 113) 7, 2011 O.J. (C 252) 28 (withdrawn); Case C-61/11, Mrad, 2011 O.J. (C 113) 8, 2011 O.J. (C 252) 28 (withdrawn); Case C.63/11, John Austine, 2011 O.J. (C 120) 5, 2011 O.J. (C 252) 28 (withdrawn); Case C-94/11, Survival Godwin, 2011 O.J. (C 139) 14, 2011 (C 252) 29 (withdrawn); Case C-113/11, Cherni, 2011 (C 238) 4 (withdrawn); Case C120/11, Yeboah Kwadwo, 2011 O.J. (C 145) 17 (removed from register); Case C-140/11, Demba Ngagne, 2011 O.J. (C 152) 16, 2011 O.J. (C 252) 29 (removed from register); Case C-156/11, Tbrahim Music, 2011 O.J. (C 269) 20 (removed from register); Case C-169/11, Conteh, 2011 O.J. (C 173) 8 (removed from register); Case Case C-187/11, Vermisheva, 2011 (C 211) 11 (removed from register).

237. Case C-61/11 PPU, Hassen El-Dridi alias Karim Soufi, 2011 ECJ EUR-Lex LEXIS 1027, para. 25 (Apr. 28, 2011). 
The Italian government argued that its use of criminal law put the detention outside the scope of the RD, relying on Article 2(2)(b). ${ }^{238}$ In one sentence, the Court rejected that plea. ${ }^{239}$ The AG clarified that the exception only applied where the return obligation was applied as a result of a criminal conviction. In the instant case, the return obligation was the predicate act to the criminal offense, and so the exception was not applicable. ${ }^{240}$

The CJEU characterized the national legislation as providing for detention "on the sole ground" that the migrant was in breach of the order to leave. ${ }^{241}$ In contrast, the Court described the RD as establishing a "fixed order" of "various, successive stages" of the removal process, ${ }^{242}$ which must employ the "least coercive measures possible." 243 Detention, the "most serious constraining measure," was "strictly regulated" in order to ensure observance of fundamental rights. ${ }^{244}$ Having confirmed the direct effect of Articles 15 and 16 of the RD, ${ }^{245}$ the CJEU identified various ways in which "the removal procedure provided for by the Italian legislation at issue in the main proceedings [was] significantly different from that established by that directive."246 These differences included the absence of a period for voluntary departure ${ }^{247}$ and the recourse to criminal detention. ${ }^{248}$

The CJEU reassured the Member States that they may still take "[coercive] measures, including criminal law measures, aimed inter alia at dissuading those nationals from remaining illegally on those States' territory." 249 However, those measures, even in the criminal law field, must be adjusted to ensure compliance with EU law, ${ }^{250}$ and ensure its effectiveness. ${ }^{251}$ The principles of proportionality and effectiveness precluded any national rule that provided for a custodial sentence "on the sole ground" that the TCN continued to stay illegally after the order has been issued. Instead, Member States must "pursue their efforts to

238. Id. para. 49 .

239. Id. paras. 48-49. At issue was the exclusion of those facing deportation for criminal reasons under Article 2(2)(b) of the Returns Directive. See RD, supra note 10, art. 2(2)(b).

240. El-Dridi, 2011 ECJ EUR-Lex LEXIS.1027, paras 22-28.

241. Id. para. 29 .

242. Id. para. 34 .

243. Id. para 39 .

244. Id. para. 42.

245. Id. paras. 44-47.

246. Id. para. 50.

247. Id. para. 51.

248. Id. paras. 52-60.

249. Id. para. 52.

250. Id. para. 54.

251. Id. paras. 55-56. 
enforce the return decision, which continues to produce its effects."252 The CJEU noted that detention in this circumstance risked making removal more difficult. 253

The result is startling: The RD precludes the Italian law. As EU law is supreme over national law, national courts are obliged not to apply those provisions of the Italian law which are incompatible with the RD, taking into account the general principle "of the retroactive application of the more lenient penalty." 254 This duty, incumbent on all national judges irrespective of their position in the national judicial hierarchy, has been a hallmark of EU law since its early years. ${ }^{255}$

\section{The Looming Question of Preemption}

EU law's capacity not only to penetrate the domestic legal order, but also to shift aside other domestic norms and make way for its own "full effectiveness" is truly distinctive. The question left unasked and unanswered in Kadzoev is of great constitutional significance for the relationship between the EU and its Member States. If Kadzoev can no longer be detained under the RD, what residual power does the Member State have detention-wise?256 $\mathrm{El}$-Dridi takes up this issue in regard to criminal detention. The AG and the CJEU are not ad idem on the extent of preemption. The AG notably took issue with the inherent nature of criminal law, described as a "repressive reaction." 257 For the AG, both criminalization per se and detention as the specific penalty were liable to impede the achievement of the RD's aim. ${ }^{258}$ In contrast, the Court expressly leaves more leeway for national criminal measures in this field. ${ }^{259}$ Indeed, in emphasizing that the offending

252. Id. para. 58.

253. Id. para. 59.

254. Id. para. 61.

255. See Case 106/77, Simmenthal, 1978 E.C.R. 629.

256. This form of preemption, where the EU rules preempt national ones because the latter impede the effectiveness of the former is "the most hazy and ill-defined" form of preemption in EU law. Amedeo Arena, The Doctrine of Union Preemption in the EU Single Market: Between Sein and Sollen 31 (The Jean Monnet Ctr. for Int'l and Reg'l Econ. Law \& Justice, Working Paper 03/10, 2010). The other forms are field pre-emption (where EU rules in the field preclude national action in that field) and rule pre-emption (where an EU norm precludes a contradictory national one.) Arena's account focuses on pre-emption in the context of the EU's single market. He notes in his conclusion that investigating the "preemptive effects on EU legislation in the area of freedom, security and justice" is of "paramount importance." Id. at 90.

257. Case C-61/11 PPU, Hassen El-Dridi alias Karim Soufi, 2011 ECJ EUR-Lex CELEX LEXIS 1027, para. 40 (Apr. 28, 2011).

258. Id. para. 43.

259. Id. para. 52. 
aspect of the Italian legislation was that detention was "on the sole ground" of staying in the face of the order to leave, the CJEU seems to implicitly allow for other criminal offenses based on illegal residence coupled with some other elements of wrong-doing, provided that this did not make deportation more difficult. The difference in approach between the AG and the Court will require resolution shortly. ${ }^{260}$ While the approach in El-Dridi seems capable of taming some of the punitive excesses of the moves toward the criminalization of migration, it brings a sense of disquiet too. If criminalization was demonstrated to be effective in achieving deportation, then one would fall back on the principle of proportionality alone to restrain it under EU law, in which case the notion that the $\mathrm{RD}$ would preempt the national rules would be a much more audacious claim.

As for the notion of residual "public order" detention powers, there is certainly no general "public order" power to detain under Article 5 ECHR. The grounds for detention set out there are finite. ${ }^{261}$ The Court has interpreted the potentially broadest ground, which permits detention "to secure the fulfillment of an obligation prescribed by law" narrowly, requiring a specific identifiable legal obligation in view. ${ }^{262}$ Even in times of emergency, detention powers must be exercised in a nondiscriminatory fashion. Singling out foreigners for special forms of detention, other than under Article $5(1)(f)$, is not permissible. This is best illustrated by the rulings in the Belmarsh litigation saga, culminating in the ECtHR Grand Chamber ruling in A. v. U.K. ${ }^{263}$ Nonetheless, many Member States do have anomalous detention grounds that cannot be subsumed under the ECHR purposes, ${ }^{264}$ and so are of questionable legality under the ECHR. If such grounds impede the effectiveness of the removal, the RD may also preclude them.

\footnotetext{
260. Case C-329/11 Alexandre Achughbabian v Préfet du Val-de-Marne, lodged on 29 June 2011.

261. For a discussion, see Fundamental Rights Agency, supra note 97, at 19.

262. Engel v. Netherlands, 1 Eur. H.R. Rep. 647 (1976).

263. A. v. United Kingdom, App. No. 3455/05 Eur. Ct. H.R. (2009) http://www.echr.coe.int/ echr/en/hudoc (follow "HUDOC database" hyperlink; search "Application Number 3455/05").

264. As the FRA has recently highlighted, in the Czech Republic, Finland, Greece, Germany, and Hungary, additional reasons (such as the threat posed to public order) are used to determine whether to place individuals in predeportation detention. The practices are difficult to square with the requirement that detention be strictly necessary for the purpose of effectuating removal. In other Member States (Latvia, Lithuania, and Malta), public order and other non-Article 5 grounds, seem per se to justify detention of foreigners. Fundamental Rights Agency, supra note 97, at 19-20.
} 


\section{CJEU-ECtHR Interactions}

In Kadzoev, the reasoning of AG Mazák and of the Court are similar, but, as is typically the case, the AG's View is more elaborate, particularly in its engagement with the ECtHR authorities. In regard to the "reasonable prospect of removal" under Article 15(4) of the RD, the AG cited the Council of Europe material, in particular the CAHAR Guideline Number Seven on Forced Return. ${ }^{265}$ The AG noted that EU law also incorporated the Article 5(1)(f) ECHR standards, 266 citing Chahal ${ }^{267}$ and Mikolenko. 268 The AG emphasized the ECtHR requirement of due diligence, in order to ensure that periods in detention are as short as possible. 269 The AG's view was decided on November 10, 2009, less than a month after the ECtHR ruled in Mikolenko that detention was unlawful as there was no reasonable prospect of removal. ${ }^{270}$ Given the proximity in time, it is unsurprising that the AG would cite this case, particularly since both cases concern impediments to removal due to insufficient cooperation from the receiving country. Unlike the Court, the AG gave a strong indication that the detention should be regarded as unlawful in the absence of a reasonable prospect of removal.

However, Kadzoev signals that the RD standards are higher than the ECHR in other crucial respects, namely in requiring that detention is necessary to effectuate removal, ${ }^{271}$ and in imposing a strict time limit. In El-Dridi, the Court noted that the RD was intended to take account of both the Strasbourg case law "according to which the principle of proportionality requires that the detention of a person against whom a deportation or extradition procedure is under way should not continue for an unreasonable length of time, that is, its length should not exceed that required for the purpose pursued" and the guideline providing that detention is to be "for as short a period as possible." ${ }^{72}$ In this way, the

265. Case C-357/09 PPU, Kadzoev, 2009 E.C.R. I-11189.

266. Id. para. 53 (citing Chahal v. United Kingdom, App. No. 22414/93, 23 Eur. H.R. Rep. 413 (1997); Mikolenko v. Estonia, App. No. 10664/05 Eur. Ct. H.R. (2009), http://www.echr.coe.int/echr/en/hudoc (follow "HUDOC database" hyperlink; search "Application Number 10664/05"); Twenty Guidelines on Forced Return, supra note 94 (Guideline No. 7)).

267. Chahal v. United Kingdom, App. No. 22414/93, 23 Eur. H.R. Rep. 413 (1997).

268. Mikolenko v. Estonia, App. No. 10664/05 Eur. Ct. H.R. (2009), http:/www.echr.coe.int/ echr/en/hudoc (follow "HUDOC database" hyperlink; search "Application Number 10664/05").

269. Case C-357/09 PPU, Kadzoev, 2009 E.C.R. I-11189, para. 4.

270. Mikolenko, App. No. 10664/05 Eur. Ct. H.R. (2009).

271. Case C-357/09 PPU, Kadzoev, 2009 E.C.R. I-11189, para. 64.

272. See Case C-61/11 PPU, Hassen El-Dridi alias Karim Soufi, 2011 ECJ EUR-Lex LEXIS 1027, para. 43 (Apr. 28, 2011) (citing to Saadi v. United Kingdom, App. No. 13229/03, 47 Eur. H.R. Rep. 17, para. 72, para. 74 (2008); Twenty Guidelines on Forced Return, supra note 94 (Guideline No. 8)). 
CJEU reads in the Strasbourg requirements as to the duration of detention, making clear that the eighteen-month time limit is the outer limit, which will not be justified in all cases. However, as we have seen, the ECtHR rejects the requirements of necessity and proportionality in its case law, but reads the requirement of "reasonable time" into its conception of nonarbitrariness. It would be regrettable if the distinctive EU version of proportionality were to be sapped of vigor by converging on the weak ECHR non-arbitrariness standard.

The AG in Kadzoev also cited the Strasbourg case law to clarify that although asylum seekers could not be detained under the RD, "detention of an asylum applicant [was] not, as such, prohibited under the international and [EU] law of asylum."273 While the judgment is crucially important in delimiting the detention of asylum seekers from those facing deportation, it should not be taken to endorse the view that the ECHR standards in Saadi ${ }^{274}$ should be incorporated into EU law in toto. Rather, as demonstrated above, the EU legislative framework contains the building blocks for more rigorous scrutiny of detention of asylum seekers. Constructive human rights pluralism stands for critical engagement, not automatic integration. The EU legislative framework and its imminent commitment to rigorous proportionality review, warrant a different approach.

\section{CONCLUSION}

The proliferation of rights sources and adjudicative bodies with overlapping jurisdiction may give the appearance of a rights surfeit. Yet, the cases reveal a burgeoning practice of immigration detention. The HRC has used a vague, capacious notion of "arbitrariness" to condemn automatic detention of migrants, instead demanding individual justification. But, the permissible aims of detention remain open under its jurisprudence. Regrettably, neither the ECtHR nor the CJEU gives due weight to the HRC authorities. The ECtHR takes an eccentric course, particularly in refusing to apply its standard proportionality approach, and in allowing the state unlimited leeway to deem migrants unauthorized. The two leading rulings, Chahal and Saadi, sit poorly with the authority of the HRC and the RC, as well as

273. Case C-357/09 PPU, Kadzoev, 2009 E.C.R. I-11189, para. 85 (citing, e.g., Saadi v. United Kingdom, App. No. 13229/03, 47 Eur. H.R. Rep. 17 (2008); Riad v. Belgium, App. No. 29787/03 Eur. Ct. H.R. at 74-76 (2008), http://www.echr.coe.int/echr/en/hudoc (follow "HUDOC database" hyperlink; search "Application Number 29787/03 "); Human Rights Comm., A. v. Australia, Commc'n. No. 560/1993, para. 9.2, U.N. Doc. CCPR/C/59/D/560/1993 (1997).

274. Saadi, App. No. 13229/03, 47 Eur. H.R. Rep. 17 (2008). 
with the standards now binding on the bulk of ECHR parties via EU law. A necessity test and authorized presence at least for asylum seekers once admitted to the procedure are acknowledged features of the EU regime.

Constructive human rights pluralism would have Strasbourg engage in a less perfunctory manner with the IHRL standards and align with them, when appropriate. The existence of the EU standards should exert pressure for that movement from within. EU law, despite the apparently unpromising legislative framework, has integrated the better aspects of the ECtHR jurisprudence, superimposing the necessity requirement that the ECtHR erroneously rejected. Guiraudon's prediction of the "bold" CJEU and the "tamer" ECtHR seems to be playing out. ${ }^{275}$ It would be wrong for the EU to converge on the ECHR minimum when it is called upon to articulate its own interpretation of the right to liberty. Thus far, given the nature of the claims before it, textual fidelity to the RD has produced outcomes that are evidently more rights-protective than the ECHR. In future cases, it may be called upon to develop its own distinctive jurisprudence on the right to liberty and should be wary of the overblown statism that animates the Strasbourg case law.

Much depends on national judges. They trigger preliminary references, and their questions not only dictate the scope of the CJEU's jurisdiction but may nudge the Luxembourg judges in particular directions. While the referring court in Kadzoev seemed incredulous that release from detention was required as a matter of EU law, the questions referred in $\mathrm{El}$-Dridi seem part of a concerted judicial effort to thwart the criminalization of irregular migration in Italy. The Italian government's argument in El-Dridi, that its use of criminal law prevented the application of the $\mathrm{RD}$, has a naive ring to it. The outcome, wherein the RD instead "precludes" the Italian law, shows that the state qua EU Member no longer controls the exception. At the other end of the enforcement spectrum, we might contrast the distortion of the scope of the RC by governments keen to treat "asylum seekers" as presumptively "bogus" rather than presumptive refugees. The article began with the statist assumption, and the migrant's vulnerability to naked state power. EU law takes a different view of the state, unsettling statist assumptions, and opening up space for greater normative contestation. The universal subject, the rights-bearer, appears a more vivid prospect under EU law than under IHRL.

And yet, I have not described a continent at ease. Immigration detention continues to increase, and Member States are raising

275. See Guiraudon, supra note 84. 
detention time limits in response to the RD. EU law brings us "[d] tainees [who] have more rights, but they are detained for longer periods of time,"276 But at least, once the maximum period of detention expires, release is required. But then what? Once Kadzoev and El-Dridi are released from detention, their irregular status remains. Periodic mass regularizations of irregular migrants are routine in EU Member States, ${ }^{277}$ and increasingly justified in human rights terms. ${ }^{278}$ Mincheva suggests the implicit next step for Kadzoev should be regularization. ${ }^{279}$ Yet, EU law offers no solution at present and may even be seen to exert an anti-regularization ethos over its Member States. ${ }^{280}$ The ECHR protects some migrants from removal based on their long residence, but does not provide them with a formal status in the host state. ${ }^{281}$ There is no clear supranational legal remedy at present. It appears the best we can hope for is that supranational courts and authority will prompt inclusive political and judicial moves at the domestic level.

276. FLYNN \& CANNON, supra note 2, at 9 (reporting the statement of an EU workshop participant).

277. For an overview of regularization practices, see MARTIN BALDWIN-EDWARDS \& AlBERT KRALER, INT'L CTR. FOR MigRATION POLICY DEV., REgINE: REgULARIZATIONS IN EUROPE: STUdy ON PRACTICES IN THE AREA OF REgULARIzation IN THE MEMBER STATES OF THE EU-FINAL REPORT (2009).

278. See Albert Kraler, Fixing, Adjusting, Regulating, Protecting Human Rights-The Shifting Uses of Regularisations in the European Union, 13 EUR. J. OF MIGRATION AND L. 297 (2011).

279. See Mincheva, supra note 220.

280. The problems posed by nonremovable irregular migrants have long been noted, but even a suggestion to study the various Member State practices concerning nonremovable migrants with a view to developing some common principles at the EU level was dropped. Kraler, supra note 278 , at 301 .

281. See, e.g., Bonger v. The Netherlands, App. No. 10154/04 Eur. Ct. H.R. (2005) http://www.echr.coe.int/echr/en/hudoc (follow "HUDOC database" hyperlink; search "Application Number 10154/04"). In rare cases, Article 8 ECHR may provide a basis for a claim to regularize a migrant's stay. See generally Daniel Thym, Respect for Private and Family Life Under Article 8 ECHR in Immigration Cases: A Human Right to Regularize Illegal Stay?, 57 INT'L \& COMP. L. Q. 87 (2008). 
